\title{
Meta-analysis to predict the effects of metabolizable amino acids on dairy cattle performance
}

\author{
I. J. Lean, ${ }^{*}$ M. B. de Ondarza,† C. J. Sniffen,ł J. E. P. Santos,§ and K. E. Griswold\# ${ }^{1}$ \\ *Scibus, PO Box 660, Camden 2570, New South Wales, Australia \\ †Paradox Nutrition LLC, West Chazy, NY 12992 \\ ‡Fencrest LLC, Holderness, NH 03245 \\ §Department of Animal Sciences, University of Florida, Gainesville 32611 \\ \#Kemin Industries Inc., Des Moines, IA 50317
}

\begin{abstract}
Meta-analytic methods were used to determine statistical relationships between metabolizable AA supplies and milk protein yield, milk protein percentage, and milk yield in lactating dairy cows. Sixty-three research publications (258 treatment means) were identified through a search of published literature using 3 search engines and met the criteria for inclusion in this metaanalysis. The Cornell Net Carbohydrate and Protein System (CNCPS) version 6.5 was used to determine dietary nutrient parameters including metabolizable AA. Two approaches were used to analyze the data. First, mixed models were fitted to determine whether explanatory variables predicted responses. Each mixed model contained a global intercept, a random intercept for each experiment, and data were weighted by the inverse of the SEM squared. The second analysis approach used classical effect size meta-analytical evaluation of responses to treatment weighted by the inverse of the treatment variance and with a random effect of treatment nested within experiment. Regardless of the analytical approach, CNCPS-predicted metabolizable Met $(\mathrm{g} / \mathrm{d})$ was associated with milk protein percentage and yield. Milk yield was positively associated with CNCPS-predicted metabolizable His, Leu, Trp, Thr, and nonessential AA (g/d). Milk true protein yield was also associated with CNCPS-predicted metabolizable Leu $(\mathrm{g} / \mathrm{d})$. Predicted metabolizable Lysine $(\mathrm{g} / \mathrm{d})$ did not increase responses in production outcomes. However, mean metabolizable Lys supply was less than typically recommended and the change with treatment was minimal (157 vs. 162 g; 6.36 vs. $6.38 \%$ metabolizable protein). Experiments based solely on Lys or Met interventions were excluded from the study database. It is possible that the inclusion of these experiments
\end{abstract}

Received December 20, 2016.

Accepted September 12, 2017.

${ }^{1}$ Corresponding author: ken.griswold@kemin.com may have provided additional insight into the effect of these AA on responses. This meta-analysis supports other research indicating a positive effect of Met and His as co-limiting AA in dairy cows and suggests Leu, Trp, and Thr be given greater consideration in future research.

Key words: amino acids, milk protein, meta-analysis, lactating dairy cow

\section{INTRODUCTION}

With the development of more refined nutrition models, increased feed prices, the greater value placed on milk protein as well as a greater awareness of the consequences of excess $\mathrm{N}$ feeding, nutritionists and dairy producers desire a better understanding of AA that increase milk protein and milk yield in dairy cows to enhance productivity while feeding diets with less CP content. Lysine and Met have been considered the most limiting AA in North American diets for lactating dairy cows (NRC, 2001) with recent experiments reinforcing this conclusion (Noftsger and St-Pierre, 2003; Socha et al., 2005; Appuhamy et al., 2011). Two independent assessments of AA research have determined Lys and Met requirements of 7.2 to 7.3 (\%MP) and 2.5 (\% MP; Rulquin et al., 1993; Doepel et al., 2004) similar to those of NRC (2001; 7.2 and $2.4 \%$ MP). However, the meta-analysis of Patton (2010) concluded that rumenprotected Met supplementation (2.35\% MP) increased milk true protein percentage and yield, but Lys at $7.3 \%$ MP was not required for this response, suggesting that other nutrient effects may need more consideration.

Other AA may limit or co-limit milk and milk protein yield in the dairy cow. Histidine has been identified as an AA that may increase production (Chamberlain and Yeo, 2003; Weekes et al., 2006; Lee et al., 2012a,b). Giallongo et al. (2015) observed no response to rumenprotected Met supplementation and slow-release urea when a MP-deficient diet based on corn silage was fed, but added rumen-protected Met and His fed together 
with a slow-release urea increased DMI, milk protein concentration, and yield. Doepel et al. (2004) recommended a dietary His concentration of $2.4 \%$ of the MP. Arginine has been suggested as an important AA for milk protein synthesis especially as a precursor for Orn, Pro, and Glu (Mepham, 1982). However, milk protein responses to changing Arg supplies have been limited (Doepel and Lapierre, 2011; Haque et al., 2013). Increases in Ile supply have increased milk yield perhaps by increasing milk lactose production (Robinson et al., 1999). Others reduced Ile supply with no negative effect, but recognized that relationships among other branched-chain AA (Val and Leu) may be involved in defining Ile needs (Haque et al., 2013). The effects of the aromatic AA, Phe and Trp, have not been extensively researched in dairy cows. However, their importance in swine nutrition has long been known (Lellis and Speer, 1987; Guzik et al., 2002). Interestingly, Holstein steers given an abomasal infusion of Phe had improved ruminal NDF digestion because of reductions in rumen passage rates (Vite et al., 2013).

Our objective was to predict the metabolizable AA (g/d) most likely to affect milk and milk protein production of dairy cattle based on Cornell Net Carbohydrate Protein System (CNCPS) version 6.5 model predictions of nutrients supplied from individual treatments described in a large number of published experiments. Changes to the CNCPS model and feedbank to CNCPS 6.5 have been published and evaluated (Higgs et al., 2012, 2015; Van Amburgh et al., 2015). It was hypothesized that milk protein yield would be predicted by dietary factors, DIM, recombinant bST (rBST) use, and estimated metabolizable AA flux (g/d). Further, differences in milk protein yield between protein or AA intervention groups and controls would be predicted by the same dietary factors. These different hypotheses required different statistical approaches; the first hypothesis was evaluated using mixed models and the second using classical meta-analytical methods. Similar hypotheses were explored for the secondary outcomes of milk yield and milk protein percentage.

\section{MATERIALS AND METHODS}

\section{Literature Search and Diet Description}

A comprehensive literature search of English language literature published before 2015 was conducted to identify dairy cattle research studies involving treatments designed to produce variable intestinal AA supplies, as assessed using the CNCPS 6.5 model, by using protein and AA alterations to diets or by infusion. Three search engines, Science Direct, Google Scholar, and PubMed, were used with a defined and repeatable search strategy using the terms "dairy cow," "dairy cattle," "amino acid," "milk yield," and "milk production" to identify relevant studies.

\section{Inclusion and Exclusion Criteria}

All published studies were screened using standardized criteria. For inclusion into the meta-analysis, studies needed to have the following: English language, diet definition that specified individual dietary ingredients and provided forage analyses, detailed production responses including DMI, milk yield, and milk components with measures of variance, and an experimental design that included a negative control group. Experiments included in the meta-analysis represented a typical range in productivity and diet composition observed on commercial dairies. Experiments involving primarily transition cows (immediately postcalving) were excluded. Experiments that altered only Met or Lys intakes were excluded. It was a concern that the large number of studies that solely altered Met or Lys intakes may provide a database that would not allow an effective evaluation of the role of other AA on production. It was, further, considered that the effects of Met and Lys interventions would be evident, if such effects were strong. Further, because the CNCPS 6.5 model relies on the definition of specific protein and carbohydrate fractions and their corresponding rates of degradation (Van Amburgh et al., 2013), experiments in which these fractions could not be confidently predicted, such as those with poorly described heat-treated proteins or uncommon ingredients that were not present in the CNCPS 6.5 feedbank such as palm kernel meal, were excluded. Both randomized and Latin square design studies were included after investigation of the standard errors of each and the effect of study design on outcomes. One hundred ninety experiments were initially identified for review. One hundred twenty of these experiments were rejected due to limited diet definition, very low DIM, or changes only in Met or Lys intake. Seven experiments that were improperly controlled were rejected, leaving 63 experiments. Appendix Table A1 lists the experiments that were rejected and reasons for rejection.

\section{Data Extraction}

Response means and measures of variance (SD or SE) were organized into an Excel (Microsoft Corp., Redmond, WA) spreadsheet with experiment, experimental design, cows per treatment, DMI, milk yield, milk components, BW, DIM, rBST treatment, and dietary parameters. Diet nutrient profiles were obtained by en- 
tering diet and feed analysis data from each experiment into CNCPS 6.5 (NDS platform, RUM\&N Sas, Reggio Emilia, Italy) to predict nutrient parameters including individual metabolizable AA supplied (Van Amburgh et al., 2013). First, feed dictionary nutrient analyses from CNCPS 6.5 were used for diet ingredients but edited using any reported analyses. Next, the CNCPS 6.5 calculated nutrient composition of the control diet was compared with that reported. If necessary, feed and forage analyses were revised to equate reported and calculated diet nutrient compositions. Preference was given to revising nutrient compositions of forages and feed ingredients known to be variable. No nutrient content revisions beyond expected typical biological variation were acceptable. Consequently, several studies without equivalent calculated and reported diet nutrient compositions were excluded from the data set (Appendix Table A1). No further corrections were made to the feed analyses to match the treatment diet analyses on the basis that given the same forages were used for treatment and control diets, any tested difference in the comparison to the treatment diet analyses would likely reflect the distribution of errors around feed sampling and analysis. Similar methods for extraction and calibration of the feed data have been described by the authors previously (Rabiee et al., 2012) and by others (White et al., 2017).

\section{Statistical Analysis}

Data were extracted from the experiments and entered into 2 final data formats. One was structured to provide each treatment as a single line entry to determine whether the explanatory variables explained milk protein yield, milk yield and milk protein percentage. The second database was structured to allow a classical meta-analytical evaluation of differences in responses of the experimental groups in milk protein yield, milk yield, and milk protein percentage to the differences in interventions used in the experiments. These data have a hierarchical structure because many experiments used multiple treatments. Consequently, there is dependence within experiment and the effects of experiment and treatment need to be evaluated by meta-regression using multi-level models (St-Pierre, 2001; Hedges et al., 2010; Van den Noortgate et al., 2013).

Variables that were examined by meta-regression included BW (kg) and CNCPS 6.5 predicted daily intake of ADF (g), NDF (g), sugar (g), starch (g), soluble fiber $(\mathrm{g})$, rumen UFA $(\mathrm{g})$, ether extract $(\mathrm{g})$, ammonia $(\mathrm{g})$, and grams per day of CNCPS estimated metabolizable Met, Lys, Arg, Thr, Leu, Ile, Val, His, Phe, and Trp. An estimate of the NEAA mass (g/d) available as MP was derived by subtracting the sum of AA listed above in grams from the estimated MP (g). The effects of experimental design (Latin square and Youden square vs. completely randomized trials or randomized block designs), and statistical analysis methods (mixed models vs. fixed effects models) were tested using classical meta-analysis methods (Stata, version 14, StataCorp, College Station, TX), and rBST use in studies (used rBST vs. did not use rBST) using mixed models (SAS, version 9.4, SAS/STAT, SAS Institute Inc., Cary, NC), were also evaluated. The effect of rBST on production responses could only be examined using the mixed model methods, because the effect of rBST was balanced within experiment and, consequently, does not influence the difference between treatment and control groups examined using classical methods. Diversity of cattle breeds was insufficient to test for this effect. Body weight and rumen ammonia concentrations were dropped from the multivariable model evaluations because few experiments recorded these estimates.

Model Development. Initial data exploration included production of basic statistics using Stata (version 14) to examine the data for errors and to estimate the means and measures of dispersion. Normality of the data was examined for continuous variables, by visual and statistical appraisal, which were then centered, by subtraction of the mean response for that variable, to allow better interpretation of the coefficients produced in models. These are interpreted as the change in outcome associated with change in the predictor variable with other variables at their mean value (Echambadi and Hess, 2007). Correlations between variables to milk protein yield, milk protein percentage, and milk yield were explored separately and linear and quadratic relationships were examined using bivariate panel plots (Stata version 14). Collinearity among variables was subsequently explored for all models developed using the 'collin' function in Stata that provides the variance inflation index (VIF) and condition number.

Further exploration of the factors that influenced outcomes was conducted using variables that had a $P<0.2$ on univariable correlation analysis with the outcome variables. This method was used to reduce the potential for over-fitting models to the data (Dohoo et al., 2009). Initial mixed models analysis was conducted using Stata using the XTMIXED, MEGLM, and GLAMM models. The models developed in XTMIXED considered the effect of treatment nested within experiments. The different methods were used to evaluate consistency of outcome from backward stepping using different mathematical methods for model convergence. The effect of treatment within experiment_was examined as a random effect using GLAMM (Stata) to 
partition the variance components of the nested model (Rabe-Hesketh and Skrondal, 2005), but this effect did not explain substantial variation in responses above that explained by experiment alone. Only for the mixed model evaluation of protein yield $(6.6 \%)$ was more than $2 \%$ of the variance explained by the effect of experiment within publication.

A backward stepping modeling approach was used with the removal of the least significant term at each step and evidence of confounding and collinearity were evaluated by examination of change in the regression coefficients and significance of remaining variables when compared with preceding models. The model fit was assessed by evaluating the Akaike's information criteria and comparing this to previous models. Initial models using XTMIXED included the random effect of treatment and experiment.

Residuals from the random effects model were examined for heteroscedasticity by examination of plots of residuals against fitted values and normality assumptions were tested by evaluating quantiles of the standardized residuals against quantiles of the normal distribution (Rabe-Hesketh and Skrondal, 2005). However, the XTMIXED analysis does not weight the experiment according to the precision of the experiment as recommended by St-Pierre (2001), and it is a maximum likelihood model.

Final models were consequently developed and tested using the MIXED procedure of SAS (SAS version 9.4, SAS/STAT, SAS Institute Inc.) according to the methods of St-Pierre (2001). To account for heterogeneous errors across different experiments, the "Weight" statement in SAS was used to weight the observations by the inverse of their variances. For that, the inverse of the squared SEM for each treatment was divided by the mean of the inverse of the squared SEM of all treatments to center the value around 1 as suggested by St-Pierre (2001). Models included the retained fixed effects of dietary predictors, that is the estimated components of the diet from each trial, from the final models and the random effect of study. Attempts were made to fit the random effect of treatment nested within experiment using REML algorithms as recommended by St-Pierre (2001). These models did not converge, so no estimates were generated from models for the nesting of treatment within experiment. Given (1) the minor amount of variance explained by the effect of nesting trial within study and the very substantial effects of experiment, and (2) problems of convergence of the 3-level model (i.e., including treatment within experiment), final SAS models presented are 2-level models (i.e., accounting for the random effect of experiment only). The models were explored by fitting the random slopes for nutritional variables (i.e., variables apart from BST and DIM) us- ing the VC option in SAS for the covariance structure as recommended by St-Pierre (2001) to test whether responses to an intervention varied across experiments. Terms that did not vary for response across treatments, but were not significant as a fixed effect, were removed. The only model that produced a random interaction of experiment with estimated components of the diet (that is, a linear term shift for each experiment) was methionine with milk protein percentage and this was fitted with an unstructured covariance structure. The variance-covariance matrixes were evaluated to examine the homogeneity of slopes across the studies for milk protein percentage. The final models, therefore, took the form

$$
Y_{i j}=b_{0}+b_{n} X_{i j}+s_{i}+a_{i} X_{i j}+e_{i j}
$$

where $Y_{i j}$ is the expected outcome for the dependent variable $Y$ observed at level $j$ of the continuous variable $X$ in the experiment, $i=1, \ldots n, b_{0}$ is the overall intercept across all experiments (fixed), $b_{n}$ are the regression coefficients for the fixed effects of estimated components of the diet $X_{i j}$ across all experiments (fixed effect), $s_{i}$ is the random effect of experiment (i.e., an intercept shift for each experiment), $a_{i} X_{i j}$ is the random interaction of experiment with estimated components of the diet in the experiment (i.e., the linear shift for each experiment), and $e_{i j}$ is the residual error. The term $a_{i}$ only applied for the milk protein percentage model, where the

$$
s_{i} \sim N\left(0, \theta_{s}^{2}\right), a_{i} \sim N\left(0, \theta_{a}^{2}\right), \text { and } e_{i j} \sim N\left(0, \theta_{e}^{2}\right),
$$

with the covariance $\left(s_{i}, a_{i}\right)=0$, meaning that $s_{i}$ and $a_{i}$ have means of zero and variances $\theta_{s}^{2}$ and $\theta_{a}^{2}$, respectively, and have expected covariance $=0$.

The final models were assessed in SAS for collinearity using the VIF and condition index statistics using methods consistent with Cheng et al. (2010) and no evidence of collinearity was detected as indicated by VIF within both models that are always below 4 and condition indices consistently less than 5 (Appendix Table A2). It was not necessary to consider the collinearity of random effects terms in the models as only milk protein percentage contained such terms and this was a single variable.

Stata was also used to analyze differences in milk protein yield, milk yield, and milk protein percentage by standardized mean difference (SMD), which is also called effect size (ES) analysis. These methods have been published in detail in Lean et al. (2009) and Rabiee et al. (2012). The difference between treatment and control groups means, which is termed "treatment" 
in the following description, was standardized using the standard deviations of control and treatment groups. The SMD estimates were pooled using the DerSimonian and Laird (1986) random effects models. Only random effects models were used, as previous work concluded that when there was uncertainty in the evaluative units caused by clustering of observations, the random effects model was appropriate (White and Thomas, 2005).

If a paper reported separate estimates of measures of variance (SE or SD) for each group, these were recorded as such. Many experiments reported a common SE or $\mathrm{SD}$ and these estimates were applied to both control and treatment groups. A random effects weighted mean difference between treatment and control is provided, with the weighting reflecting the inverse of the variance of the treatments included according to the nostandard method in the metan model of Stata to allow an interpretation of treatment effects in familiar units, rather than ES.

Random effects models were used for each outcome variable to estimate the effect size, $95 \%$ confidence intervals, and statistical significance of SMD. It is recognized that a clustering effect results from multiple comparisons to a single control group; this effect was tested and treatment nested within experiment represented $2 \%$ of the total variance for milk yield, $1 \%$ for milk protein yield, and $0.5 \%$ for protein percentage in milk, respectively.

Forest plots of the responses were created and effects of AA interventions on milk protein yield and milk yield are displayed in Appendix Figures A1 and A2, using the estimated SMD of the outcomes.

Assessment of Heterogeneity. Variations among the treatment level SMD were assessed using a chisquared (Q) test of heterogeneity. Heterogeneity in treatments reflects underlying differences in clinical diversity of the herds and interventions, differences in experimental design and analytical methods, and statistical variation around responses. The clinical diversity of the herd includes all the nonstudy design aspects of variation, such as facility design, environment, and cow management that may be measured and controlled for in meta-analysis, but are often not reported or measured. Identifying the presence and sources of the heterogeneity improves understanding of the responses to the interventions used. An $\alpha$ level of 0.10 was used because of the relatively poor power of the $\chi^{2}$ test to detect heterogeneity among small numbers of trials (Egger and Smith, 2001). Heterogeneity of results among the treatments was quantified using the $I^{2}$ statistic (Higgins and Thompson, 2002), which was developed to measure the effect of heterogeneity on a meta-analysis from mathematical criteria that are independent of the number of treatments and the treatment effect measure. $I^{2}$ is a transformation of the square root of the $\chi^{2}$ heterogeneity statistic divided by its degrees of freedom and describes the proportion of total variation in treatment estimates that is due to heterogeneity. Further, $I^{2}$ provides an estimate of the proportion of the true variance of effects of the treatment, that is the true variance $\left(\tau^{2}\right)$ divided by the total variance observed in the treatment (Borenstein et al., 2017) that reflect measurement error. Negative values of $I^{2}$ are assigned a value of 0 ; consequently, the value $I^{2}$ lies between 0 and $100 \%$. Both $I^{2}$ and $\left(\tau^{2}\right)$ are provided to allow readers the opportunity to evaluate both metrics.

Meta-Regression. A key focus of meta-analysis is to identify and understand the sources of heterogeneity or variation of response among treatments. Metaregression analyses were used to explore the source of heterogeneity of response, using the individual SMD for each treatment as the outcome and the associated standard error as the measure of variance. Metaregression is also a technique that can formally test whether there is evidence of different effects in different subgroups of treatments (Knapp and Hartung, 2003). We have previously published the equations used in meta-regression (Rabiee et al., 2012) and refer readers to these for a description of meta-regression using the methods of Thompson and Sharp (1999) and Knapp and Hartung (2003). The ES of each treatment was regressed against the centered differences between the treatment and control group intake of the same dietary variables evaluated in the mixed models.

The DIM and rBST that were balanced across treatment and control groups were not examined in these models. Experimental design, whether experiments were Latin square, Youden square, or randomized designs (completely randomized or randomized block designs without crossover), was tested for significance univariably and in final multivariable models. While the standard errors were lower for Latin square or Youden square designs, the experimental design was not significant and $P$-values were $>0.5$ in any of the multivariable models. However, the effect of design code was retained in analyses for differences in the point directions of outcomes to be highlighted. Similarly, the effect of type of statistical analysis, fixed or random effects, was tested and found not to be significant in final models. The effect approached significance in univariable testing $(P<0.15)$ for milk and milk protein yield. This was not further evaluated. Apart from the evaluation of statistical models used, backward stepping models were used for meta-regression that included variables with a univariable value of $P<0.2$ obtained using the Knapp-Hartung method (Knapp and Hartung, 2003). Models were derived using the Knapp-Hartung method 
until the variables retained had a $P<0.1$ when a permutation model was used to develop final models. The permutation test approach for assessing the statistical significance of meta-regression methods suggested by Higgins and Thompson (2004), and programmed by Harbord and Steichen (2004) and Harbord and Higgins (2008), was used to reduce the risk of type I error as described by Rabiee et al. (2012). The data are simulated under the null hypothesis of no association between effect estimates and any covariate, yet with an unexplained component of heterogeneity according to the standard random effects meta-analysis model (Higgins and Thompson, 2004). Without loss of generality, the average effect was assigned to zero (Higgins and Thompson, 2004):

$$
\begin{gathered}
\theta_{i} \sim N\left(0, \tau^{2}\right), \\
y_{\mathrm{i}} \sim N\left(\theta_{i}, v_{i}\right) \text { for } i=1, \ldots, k,
\end{gathered}
$$

where an effect size $\theta_{i}$ is estimated by $y_{i}$ in treatment $i$ for experiment $1, \ldots, k$ with a mean of zero and variance $\tau^{2}$, and $v_{i}$ represents the within-experiment variances.

Covariates are simulated from a multivariable (standard) normal distribution so that correlation is imposed between pairs of covariates. This process provides an assessment less likely to produce a type I statistical error (Higgins and Thompson, 2004).

The results of the permutation test, which do not account for the hierarchical structure of the effects of treatment, are provided for comparison to robust regression models derived using the same starting variables that account for the nested effect of treatments within experiment (Hedges et al., 2010) and programmed as "robumeta" (Stata) and applied by Tanner-Smith and Tipton (2014). Hedges et al. (2010) developed the robust regression models to account for the 2-stage cluster sampling inherent when the effect size estimates are derived from a total of $\mathrm{n}=k 1+k 2+$ $\cdots+k m$ estimates from treatments that were collected by sampling $m$ clusters of experiments, that is several treatment estimates are derived from the same experiment. Hence, sampling $k j \geq 1$ estimates within the $j$ th cluster for $j=1, \ldots, m$. Briefly, in this test the mean effect size from a series of experiments is described as follows. In this case, the regression model has only an intercept $b 1$ and the weighted mean has the following form:

$$
b 1=\frac{\sum_{j=1}^{m} \sum_{j=1}^{k 1} w_{i j} \mathbf{T}_{i j}}{\sum_{j=1}^{m} \sum_{j=1}^{k 1} w_{i j}},
$$

where $m$ is the total number of studies, $k$ is the total number of treatments, $w_{i j}$ is the weighting for treatments within experiments, and $\mathbf{T}_{i j}$ is the vector of the ES estimates of treatments within experiments. If all the estimates in the same experiment are given identical weights, the robust variance estimate $\left(v^{\mathrm{R}}\right)$ reduces to

$$
v^{\mathrm{R}}=\frac{\sum_{j=1}^{m} w_{j}^{2}\left(\check{\mathbf{T}}_{j}-\mathrm{b} 1\right)^{2}}{\left(\sum_{j=1}^{m} w_{j}\right)^{2}},
$$

where $\check{\mathbf{T}}_{j}$ is the unweighted mean of the estimates in the $j$ th cluster, $b 1$ is the estimate of the weighted mean, and $w_{j}$ is the total weight given to estimates in the $j$ th cluster. This is a kind of weighted variance that reduces to $(m-1) / m^{2}$ times the variance, when the weights within experiment are identical, and (since the correlation coefficient $=1$ in this case) the robust regression standard error equals $1 / m$ times the variance of $\check{\mathbf{T}}_{j}$ estimated when the weights are equal. Hedges et al. (2010) highlight several important aspects of the robust model and the underlying assumptions that the correlation structure of the $\mathrm{T}_{j}$ does not need be known to compute the pooled $\mathrm{ES}$ or $\mathrm{V}^{R}$, only that the vectors of estimates from different experiments are independent and that regularity conditions are satisfied; the experiment or treatment level regressors do not need to be fixed; the theorem is asymptotic based on the number of experiments, rather than the number of treatments; and the theorem is relatively robust to regularity assumptions.

Publication Bias. Presence of publication bias was investigated using funnel plots (Figure 1), which are a simple scatter plot of the intervention effect estimates from individual treatments plotted against treatment precision. The name funnel plot arises because precision of the intervention effect increases as the size and precision of a study increases. Effect estimates from small treatments will scatter more widely at the bottom of the graph and the spread narrows for larger studies. In the absence of bias, the plot should approximately resemble a symmetrical (inverted) funnel. If there is bias, for example because smaller treatments without statistically significant effects remain unpublished, this will lead to an asymmetrical appearance of the funnel plot and a gap will be evident in a bottom corner of the graph. In this situation, the effect calculated in a meta-analysis will tend to overestimate the intervention effect. The more pronounced the asymmetry, the more likely it is that the bias will be substantial. Data were 
screened for plausible quadratic relationships for these variables by visual appraisal of univariable scatter plots between the covariate and SMD of each treatment.

\section{RESULTS AND DISCUSSION}

This meta-analysis provides statistical relationships between CNCPS estimated metabolizable AA supplies (g/d) and milk protein yield, milk protein percentage, and milk yield. Biological mechanisms driving these relationships should be considered to be associations and not necessarily causal. There were 258 individual treatments contained within 63 experiments (Table 1). Of these 21 were completely randomized experiments or randomized block design experiments and 42 were Latin square or Youden square experiments that provided 77 and 181 treatments, respectively. Fourteen experiments used fixed effects models to evaluate responses. The SEM of the fixed models was smaller for milk yield, greater for milk protein percentage, and not different for milk protein yield. The effect of fixed or random effects models on the estimates indicated that experiments that used fixed effects tended to have numerically larger responses, but the effect was not significant $(P>0.1)$ when tested in final models. This effect was dropped from the final models. The breeds used were predominantly Holstein, with 8 treatments using Ayrshires, 4 with no breed stated, and 21 with Holstein cross-breeds. There were 229 treatments in

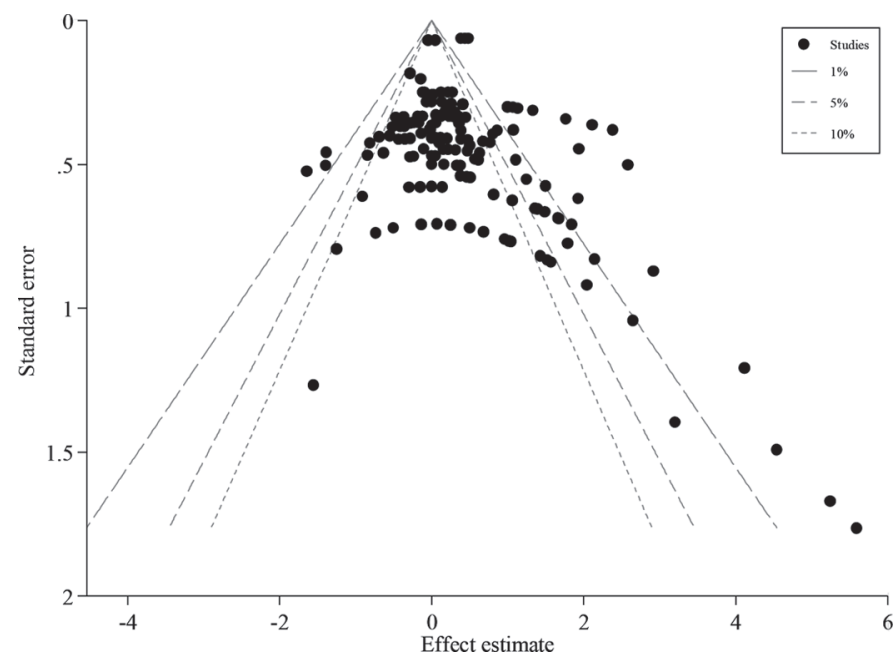

Figure 1. Contour-enhanced funnel plots for the milk protein yield $(\mathrm{kg} / \mathrm{d})$, expressed as standardized mean difference (effect size) response to protein and AA interventions. Dashed lines indicate the significance levels and treatments lying outside these are significant with $P$-values less than those lines. The positive effect sizes indicate that the interventions used increased milk protein yield. which no rBST was used and 29 treatments with rBST as an intervention. Only 12 experiments commenced treatment prepartum, whereas 246 began postpartum. Amino acids were infused in 44 treatments. The remaining treatments (214) were based solely on feeding interventions. The mean CP intake reported was 3.76 (SD 0.67) $\mathrm{kg}$, the CNCPS estimated RDP intake was 2.24 (SD 0.41) kg, and CNCPS estimated RUP 1.52 (SD 0.37) $\mathrm{kg} / \mathrm{d}$.

Table 1 provides descriptive statistics by observation for variables evaluated in the treatments. Table 2 describes the overall, control, and treatment diet composition as well as differences between control and treatment.

The choice of variables used in predictive models reflected both the inherent hierarchy in the nutritional data and consistency of responses in preliminary data investigation. Specifically, energy precursors (NDF, starch, sugars, soluble fiber, and ether extract) were included in the model rather than ME estimates, as the former are measured in the diet rather than estimated. As the focus of the study was on AA, CP was not used for prediction nor were protein fractions such as RUP or RDP. Estimates of fermentable carbohydrate fractions and rumen UFA were less associated with outcomes than carbohydrate fractions and ether extract, and were consequently excluded. A decision was made to exclude milk fat percentage as a predictive variable as use of this variable influenced the statistical analysis using the carbohydrate fractions and EE that were estimated on dietary intake.

As noted in the objectives, part of the intent of this study was to examine 2 statistical approaches for evaluating similar hypotheses. The mixed model approach provides an estimation of response with each diet contributing a different observation. The classical model treats each control and treatment evaluation as a single observation, examining the differences in responses between the treatment and control group. Consequently, some variables such as DIM and rBST use, which are balanced for the treatment and control groups, are not evaluated in the classical meta-analytical models, but are in the mixed models analysis. Therefore, responses evaluated slightly differ with the mixed model evaluating the response in treatments to the predictor variables, whereas the classical models evaluate the difference in the effect size response (SMD) of milk, milk protein percentage, or milk protein yield between treated and controls given differences in intake or availability at the small intestine of the different feeds and AA. Further, the coefficients determined are not directly comparable, as the ES is a z-score based on the standard deviation of the study variable. 
Table 1. Description of studies reviewed in this study including experimental design, number of cows, mean DIM, control diet CP (\% DM), and milk true protein $(\mathrm{TP})$ and milk yield $(\mathrm{kg} / \mathrm{d})$ of cows on control treatment

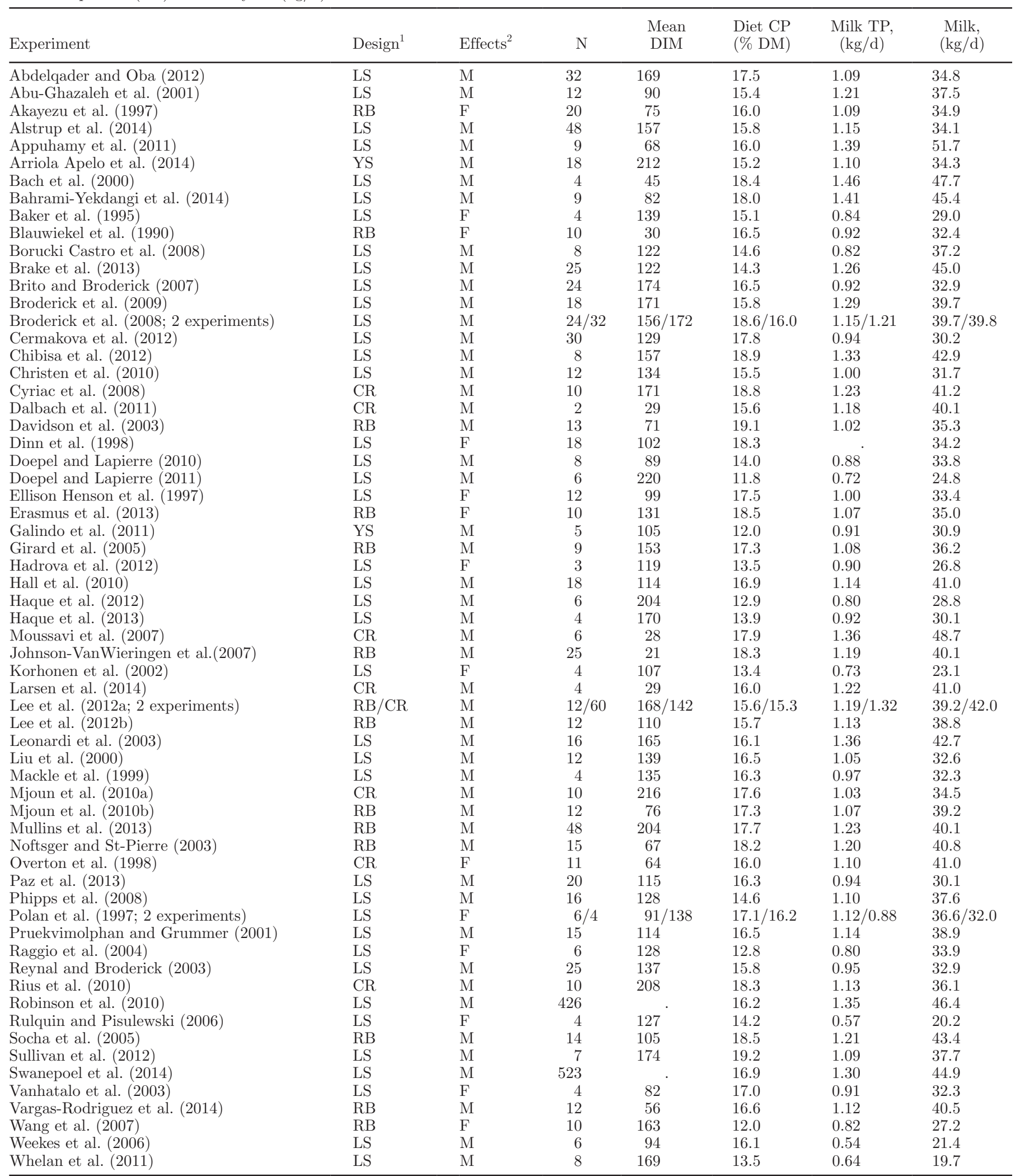

${ }^{1}$ Experimental design: $\mathrm{CR}=$ completely randomized; $\mathrm{LS}=$ Latin square; $\mathrm{RB}=$ randomized block; YS $=$ Youden square.

${ }^{2}$ Statistical model included random effects $(\mathrm{M}=$ mixed $)$ or no random effects $(\mathrm{F}=$ fixed). 


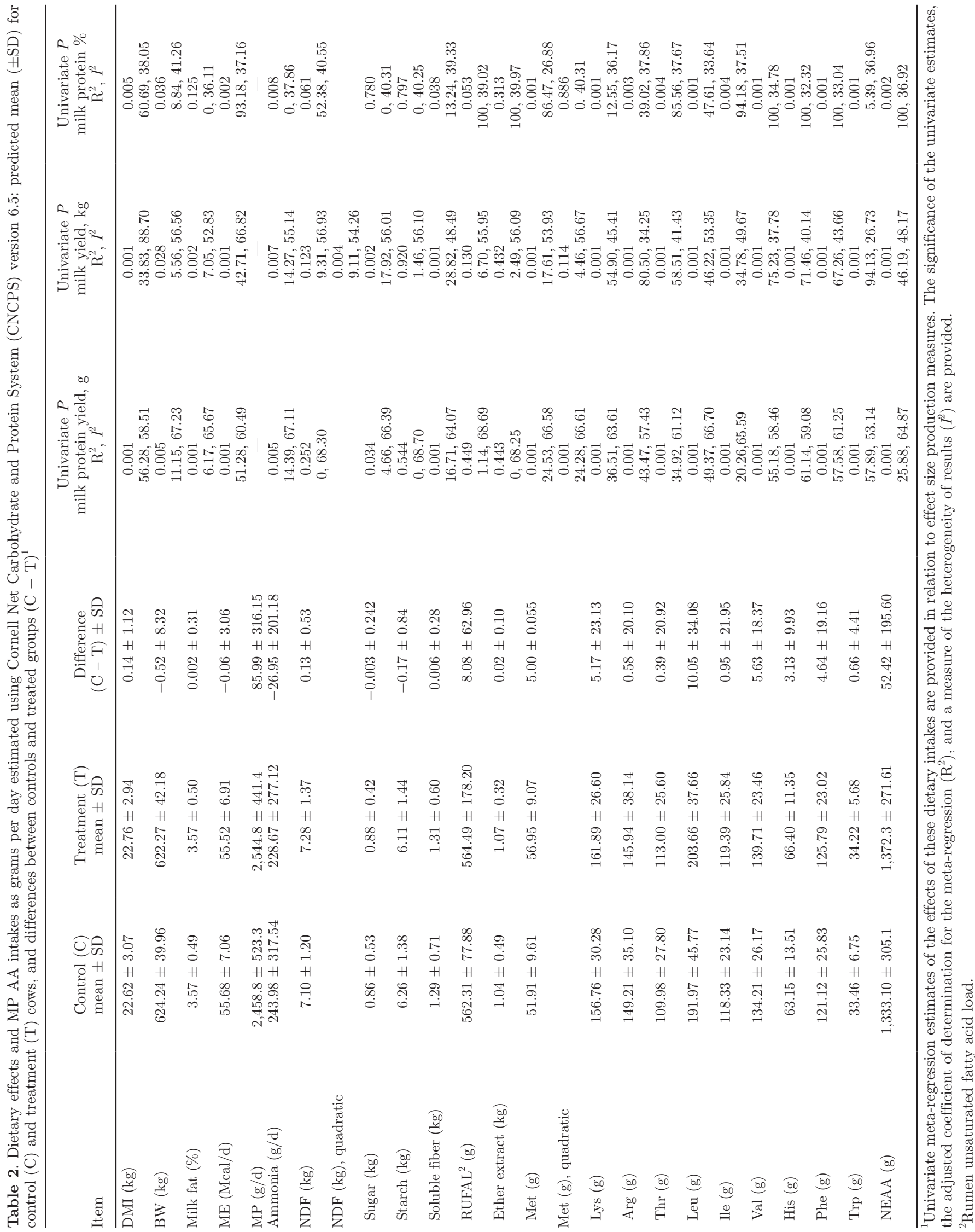


During the process of preliminary data evaluation, it was noted that there was collinearity among some estimates of CNCPS estimated MP AA flux, specifically Thr, Val, and $\operatorname{Trp}(\mathrm{r}>0.9)$. There was little indication of substantial collinearity for either the mixed model evaluation or that conducted using the classical approach, based on VIF and condition number (Appendix Tables A2 and A3). Only for the initial milk yield mixed model did the VIF for some variables exceed 10 and the condition number was 24.8, indicating cause for careful evaluation of the model development. This was monitored, for all models developed, by careful evaluation of the coefficients, evaluation of the VIF and condition index of the models developed and significance of variables if alternate variables were deleted, such as ones with a similar $P$-value. It is worth noting that coefficients can be very unstable and difficult to interpret when substantial collinearity is present, as these can vary in magnitude and even point direction. In this study, the coefficients were stable during the development of final models.

There is an apparent lack of small negative treatments published, suggesting the presence of a publication bias (Figure 1), because the plot is not symmetric around the mean effect estimate. Investigation of the distribution of these treatments found far greater symmetry and less evidence of an apparent bias once infusion treatments were removed from the data set (data not shown).

\section{Metabolizable AA (g)}

Mixed Models Analysis. The CNCPS estimated metabolizable AA (g/d) associated with better dairy cattle performance included Met and Leu, and NEAA (Table 3). Within the mixed models developed, CNCPS estimated metabolizable Met, Leu, and NEAA (g/d) were associated with increased milk protein yield $(P<$ 0.001), whereas only Met was associated with increased milk protein percentage $(P<0.0001)$. The CNCPS estimated metabolizable Leu and NEAA were associated with increased milk yield $(P<0.001)$. Lysine was not associated with milk protein yield, milk protein percentage, or milk yield in multivariable models. Days in milk had a negative linear effect on milk and milk true protein yield but a positive quadratic effect on the same outcome variables. As DIM is centered on the mean DIM of the treatments, milk protein yield and percentage and milk production responses were greater in early lactation and slightly increased toward the end of lactation, compared with mid-lactation, possibly reflecting higher milk production in experiments studies conducted in mid to late lactation (specifically 120-200 $\mathrm{d}$ in milk). The use of rBST was associated with in-

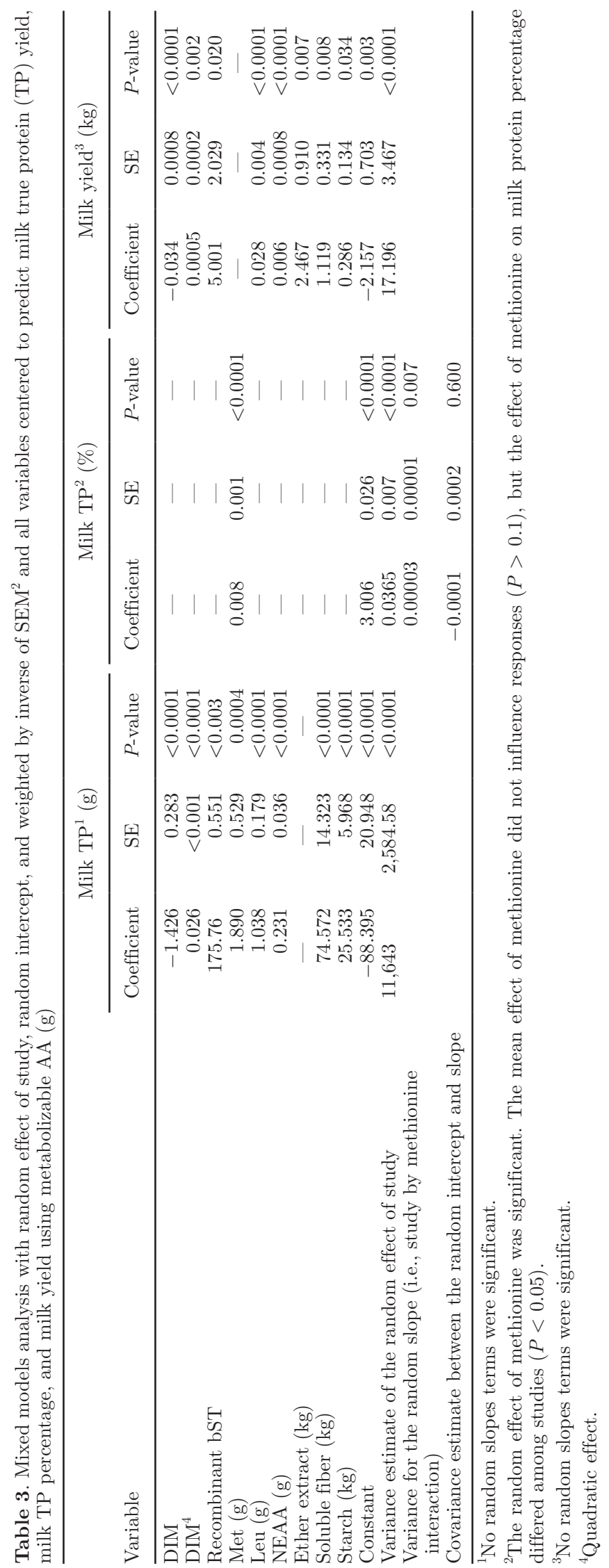

Journal of Dairy Science Vol. 101 No. 1, 2018 
Table 4. Effect size analysis to predict milk true protein (TP) yield, milk TP percentage, and milk yield using predicted dietary metabolizable AA $(g)^{1}$

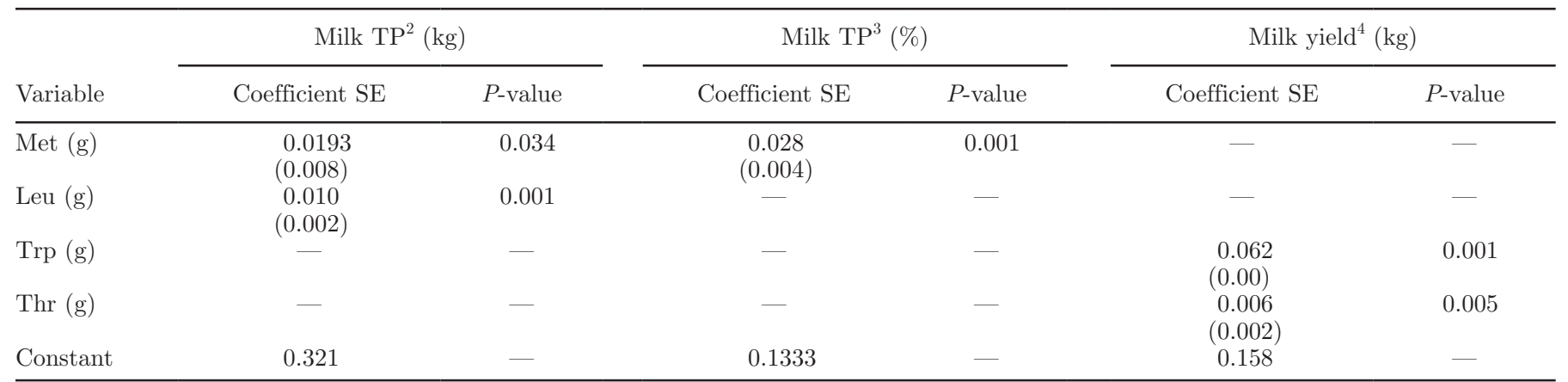

${ }^{1}$ Model coefficients and intercepts are estimated using the Knapp-Hartung method and the $P$-values are estimated using the permutation (Harbord and Higgins, 2008).

${ }^{2} \mathrm{R}^{2}=51.3, I^{2}=66.1, \tau^{2}=0.146$

${ }^{3} \mathrm{R}^{2}=86.5, I^{2}=26.9, \tau^{2}=0.003$.

${ }^{4} \mathrm{R}^{2}=92.6, I^{2}=25.7, \tau^{2}=0.010$.

creased $(P=0.02)$ milk and milk protein yield. Dietary ether extract, starch, and soluble fiber were associated with increased $(P<0.05)$ milk and milk protein yield, reflecting their positive roles in the production of rumen microbial protein, postruminal energy metabolism, and lactose production. Starch was also associated with increased $(P=0.06)$ milk protein percentage, but a final model with the random effect of diet, random intercept, and random slopes for starch and Met retained only a significant effect of Met.

Effect Size Analysis (Permutation Model and Robust Regression). Differences between the treatment group and control group in diet indicated that CNCPS estimated metabolizable Met, Leu, Trp, Thr, and His (g/d) were all associated with increased performance (Tables 4 and 5). The statistical models developed were very consistent, notwithstanding differences in that the model for milk yield as His was the last MP AA that dropped out in the mixed model and permutation analysis models, and Trp and Thr were the last variables eliminated from the robust regression. Within the statistical models developed, milk protein percentage was increased $(P<0.01)$ by $0.004 \mathrm{~kg}(0.033$ ES multiplied by an SD of 0.115 , Table 5 ) with each additional gram of Met (Tables 4 and 5; Figure 2). Methionine and Leu were also associated with milk protein yield in both models, reflecting similar findings between the classical meta-analytic model and the mixed model (Tables 3, 4, and 5; Figure 3).Milk protein yield increased by 0.002 and $0.001 \mathrm{~kg}$ with each additional gram of Met and Leu, respectively (Tables 4 and 5). Both Trp and Thr (Figure 4) were associated with increased milk yield (Table 4). Each additional gram of CNCPS estimated metabolizable Trp and Thr was associated with an increase of 0.27 and $0.02 \mathrm{~kg}$ of milk yield, respectively (Table 4 and 5 ). In the robust regression model, each gram of His was associated with $0.15 \mathrm{~kg}$ of increased milk yield (Table 5). Lysine had

Table 5. Effect size analysis to predict milk TP yield, milk true protein (TP) percentage, and milk yield using predicted dietary metabolizable AA $(g)^{1}$

\begin{tabular}{|c|c|c|c|c|c|c|}
\hline \multirow[b]{2}{*}{ Variable } & \multicolumn{2}{|c|}{ Milk $\mathrm{TP}^{2}(\mathrm{~kg})$} & \multicolumn{2}{|c|}{ Milk $\mathrm{TP}^{3}(\%)$} & \multicolumn{2}{|c|}{ Milk yield $^{4}(\mathrm{~kg})$} \\
\hline & Coefficient SE & $P$-value & Coefficient SE & $P$-value & Coefficient SE & $P$-value \\
\hline Leu (g) & $\begin{array}{c}0.010 \\
(0.003)\end{array}$ & 0.010 & - & - & - & - \\
\hline His $(\mathrm{g})$ & - & - & - & - & $\begin{array}{c}0.034 \\
(0.007)\end{array}$ & 0.001 \\
\hline
\end{tabular}

${ }^{1}$ Model coefficients and intercepts are estimated using the robust regression methods (Hedges et al., 2010).

${ }^{2}$ The SD for milk protein yield is $0.115 \mathrm{~kg}$. (The effect size multiplied by the SD provides an estimate of the coefficient in $\mathrm{g} / \mathrm{d}$.)

${ }^{3}$ The SD for milk protein percentage is 0.184 . (The effect size multiplied by the SD provides an estimate of the coefficient in $\mathrm{g} / \mathrm{d}$.)

${ }^{4}$ The SD for milk yield $(\mathrm{kg})$ is 4.338 . (The effect size multiplied by the SD provides an estimate of the coefficient in $\mathrm{g} / \mathrm{d}$.) 


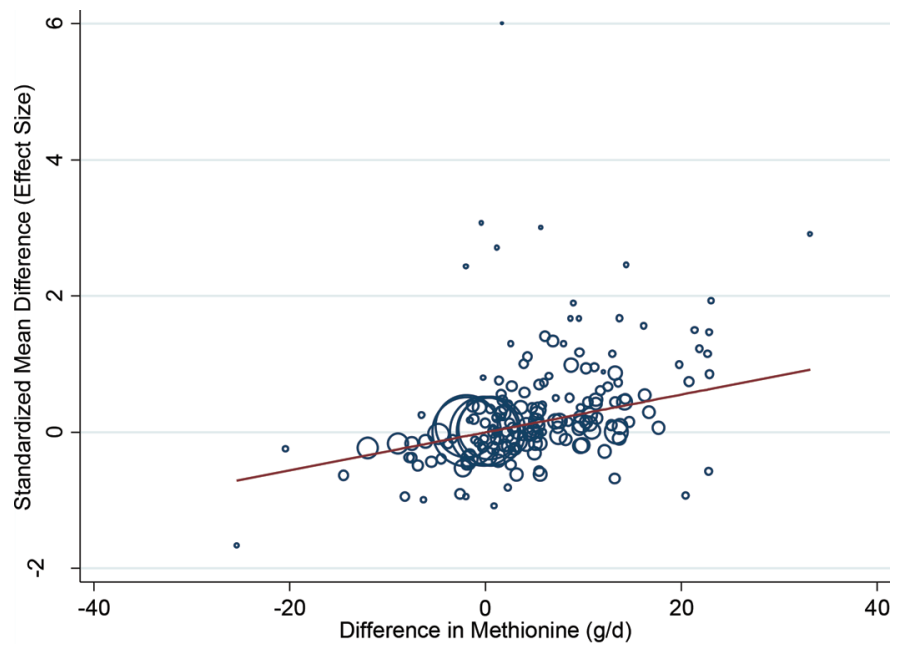

Figure 2. Meta-regression of the effect of Cornell Net Carbohydrate and Protein System estimated metabolizable Met (g/d; centered) on the standardized mean difference of treatments examining the effects of protein or AA interventions on milk protein percentage. The regression is weighted by the effect size of studies, which is indicated by the size of the marker. The larger the marker, the greater the effect size of the treatment. Color version available online.

no significant effect on milk protein yield, milk protein percentage, or milk yield in multivariable models (Tables 3, 4, and 5). Interestingly, no other predictors, such as differences in carbohydrate fractions, entered the final models, perhaps reflecting the focus of the source experiments on balancing diets for carbohydrate and fats to allow a careful examination of the effects

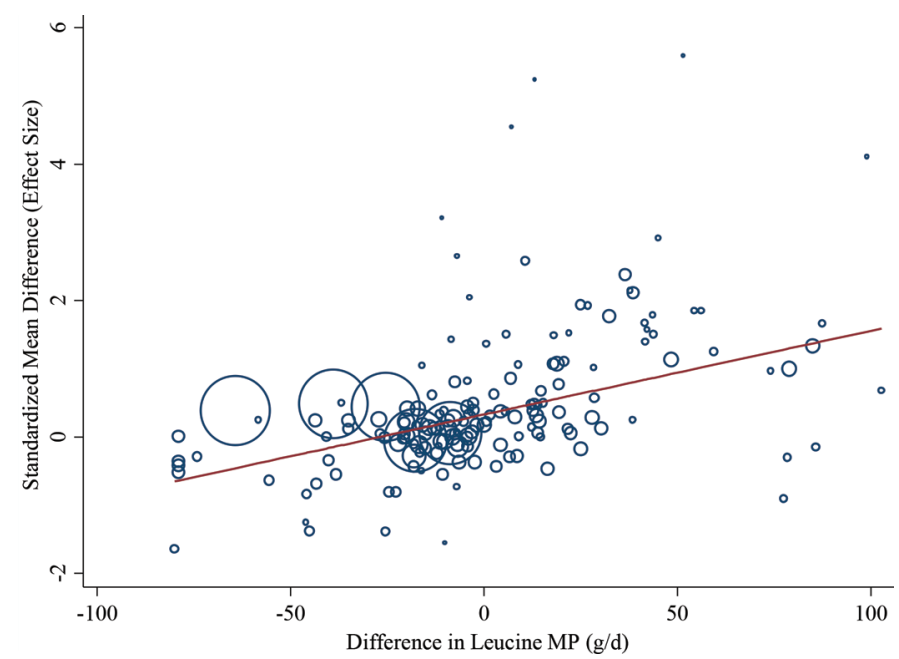

Figure 3. Meta-regression of the effect of Cornell Net Carbohydrate and Protein System estimated metabolizable Leu (g/d; centered) on the standardized mean difference of treatments examining the effects of protein or AA interventions on milk protein yield $(\mathrm{kg})$. The regression is weighted by the effect size of treatments, which is indicated by the size of the marker. The larger the marker, the greater the effect size of the treatment. Color version available online. of proteins and AA on performance. This balancing is evident in the small differences between the treatment and control means for carbohydrates and fats in Table 2. It is worth noting that this may also be a function of evaluating the difference between the treatment and control groups for an experiment in classical meta-analysis, as opposed to each treatment or control outcome being represented as a single line in the mixed models approach. Table 6 shows that treatments were effective in increasing milk protein yield and milk yield and protein percentage based on all studies evaluated using the robust regression model. The point effects estimated using completely randomized control studies can be compared with the point effects obtained using crossover experimental designs.

\section{Co-limiting Amino Acids}

Regardless of the statistical model, CNCPS estimated supply of metabolizable Met (g/d) was significantly associated with milk protein concentration and yield. Methionine was highly significant and typically had a large coefficient, indicating that a small change in Met supply of $5.5 \mathrm{~g} / \mathrm{d}$ (51.91 vs. $56.96 \mathrm{~g}$ ) (2.11 vs. $2.24 \%$ MP, Table 2) has a large positive association with milk protein percentage and yield. These effects of Met were expected based on previous research (Noftsger and St-Pierre, 2003; Socha et al., 2005; Patton, 2010; Appuhamy et al., 2011) and suggest that Met is an important AA in diets for high-producing dairy cows.

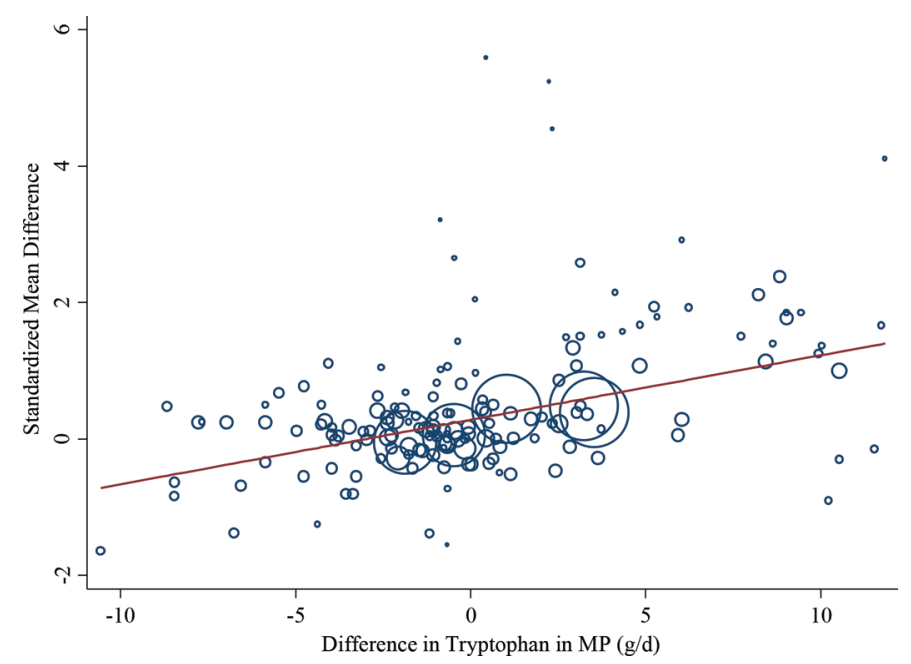

Figure 4. Meta-regression of the effect of Cornell Net Carbohydrate and Protein System estimated metabolizable Trp (g/d; centered) on the standardized mean difference of treatments examining the effects of protein or AA interventions on milk yield $(\mathrm{kg})$. The regression is weighted by the effect size of treatments, which is indicated by the size of the marker. The larger the marker, the greater the effect size of the treatment. Color version available online. 
The association between a small change in His and milk yield and suggests a role for His as a co-limiting AA in typical dairy rations. The control and treatment groups supplied 63.15 and $66.40 \mathrm{~g}$ of His, respectively, corresponding to a His of 2.57 and $2.61 \%$ MP (Table 2 ). Recent experiments have supplemented greater amounts of His $(12-16 \mathrm{~g} / \mathrm{d})$ with positive results and showed that supplemental His stimulated increased milk and milk protein yields (Lee et al., 2012b; Giallongo et al., 2015).

Milk protein yield was associated with additional CNCPS estimated Leu $(\mathrm{g} / \mathrm{d})$ in both the mixed and classical model and with milk yield in the mixed model. Tryptophan and Thr had positive effects on milk yield in the classical permutation analysis. The production responses associated with NEAA were positive for the mixed models for milk yield and milk protein yield. In contrast, Doepel and Lapierre (2010) showed no response to infused NEAA $(356 \mathrm{~g} / \mathrm{d})$.

With Lys, the consistent lack of or negative association with milk protein and milk yield was not anticipated based on previous work (Schwab et al., 1992; Vyas and Erdman, 2009). Doepel et al. (2004) recommended that the optimal AA supply for milk protein yield was 142 or $162 \mathrm{~g} / \mathrm{d}$ of digestible Lys be supplied based on their logistic curve and segmented-linear curve models, re- spectively. The supply of metabolizable Lys was 156.76 versus $161.89 \mathrm{~g}$ for control and treatment groups in this study (Table 2), and one may conclude that Lys was either not limiting, or that in our data set with many simultaneous interventions, that is, supplementation with different protein sources rather than Lys specifically, the changes in Lys were not of such magnitude to identify a significant effect in the multivariable models despite the significant univariable association with the production outcomes (Table 2). It is also worth noting that there may be differences also resulting from methods used in studies. This study relies on estimates of metabolizable Lys derived from CNCPS, whereas infusion studies should provide a more rigorous difference in metabolizable Lys availability. The possibility that subsequent development of nutritional models may provide different findings for Lys cannot be dismissed. Relative to estimated total MP, Lys was only 6.36 and $6.38 \% \mathrm{MP}$ for control and treatment, respectively, and less than the recommended $6.68 \% \mathrm{MP}$ in the CNCPS 6.5 model. Notably, only 23 of the 258 treatments in our data set started at less than 21 DIM. Potential responses to AA may be related to stage of lactation, particularly the transition period (Osorio et al., 2016). Further statistical analysis (see Appendix Table A4) using only experiments with a significant Lys intervention

Table 6. Effect size analysis to predict milk true protein (TP) yield, milk yield, and milk TP percentage for Latin square experiments (LS), randomized experiments $(\mathrm{R})$, and all experiments $(\text { all })^{1}$

\begin{tabular}{|c|c|c|c|c|c|}
\hline Outcome & $\begin{array}{l}\text { No. of } \\
\text { treatments }\end{array}$ & $\begin{array}{c}\text { Weighted mean } \\
\text { difference, } 95 \% \text { CI }\end{array}$ & $\begin{array}{c}\text { Effect size difference, } \\
95 \% \text { CI }\end{array}$ & $\begin{array}{c}\text { Heterogeneity } I^{2}(\%) \\
(P \text {-value })\end{array}$ & $\tau^{2}$ \\
\hline Milk TP (kg; LS) & 119 & - & $\begin{array}{l}0.35 \\
0.25 \text { to } 0.45\end{array}$ & $\begin{array}{l}68.2 \\
(0.0001)\end{array}$ & 0.14 \\
\hline Milk TP (kg; R) & 40 & - & $\begin{aligned} & 0.08 \\
- & 0.15 \text { to } 0.31\end{aligned}$ & $\begin{array}{l}67.9 \\
(0.0001)\end{array}$ & 0.36 \\
\hline Milk TP (kg; all) & 160 & $\begin{array}{l}0.04 \\
0.03 \text { to } 0.05\end{array}$ & $\begin{array}{l}0.31 \\
0.18 \text { to } 0.43\end{array}$ & $\begin{array}{l}68.5 \\
(0.0001)\end{array}$ & 0.17 \\
\hline Milk yield (kg; LS) & 127 & - & $\begin{array}{l}0.19 \\
0.10 \text { to } 0.27\end{array}$ & $\begin{array}{l}55.3 \\
(0.0001)\end{array}$ & 0.08 \\
\hline Milk yield (kg; R) & 50 & - & $\begin{array}{l}0.10 \\
-0.08 \text { to } 0.28\end{array}$ & $\begin{array}{l}57.3 \\
(0.0001)\end{array}$ & 0.22 \\
\hline Milk yield (kg; all) & 178 & $\begin{array}{l}0.80 \\
0.51 \text { to } 1.10\end{array}$ & $\begin{array}{l}0.17 \\
0.09 \text { to } 0.26\end{array}$ & $\begin{array}{l}55.9 \\
(0.0001)\end{array}$ & 0.10 \\
\hline Robust & & & $\begin{array}{l}0.21 \\
0.08 \text { to } 0.35\end{array}$ & & 0.0 \\
\hline Milk TP (\%; all) & 177 & $\begin{array}{l}0.03 \\
0.02 \text { to } 0.04\end{array}$ & $\begin{array}{l}0.09 \\
0.02 \text { to } 0.17\end{array}$ & $\begin{array}{l}40.0 \\
(0.0001)\end{array}$ & 0.05 \\
\hline Robust & & & $\begin{array}{l}0.20 \\
0.06 \text { to } 0.33\end{array}$ & & 0.0 \\
\hline
\end{tabular}

\footnotetext{
${ }^{1}$ Number of treatments, weighted mean differences between intervention and control groups, effect size estimates, heterogeneity, and $\tau^{2}$ estimates for the studies. The overall estimates for milk TP yield, milk yield, and milk TP percentage were calculated with the Knapp-Hartung adjustments and using robust regression methods to account for nesting of treatments within experiment.
} 
( $>20$ g difference in Lys supply between treatments; 36 experiments) also showed no positive associations with yields of milk, milk protein, or percentage milk protein, results that are consistent with those of the entire data set. Analysis of this data set also did not indicate any differences in response to Lys based on the potential for dietary Lys source to be less available than predicted by the nutrition model.

\section{CONCLUSIONS}

Notwithstanding the evaluation of 2 subtly different hypotheses and using different statistical approaches, there was good consistency in the AA identified as being associated with production. This investigation further supports the important role of CNCPS estimated metabolizable Met as a co-limiting AA in typical lactating dairy diets. The positive association of CNCPS estimated metabolizable Leu with milk protein and milk yield responses suggests that this AA be given greater consideration as potentially co-limiting. Based on the experiments reviewed, CNCPS estimated metabolizable His, Trp, and Thr may also have a significant role in limiting milk production and diets may be lacking in these and the potential to produce these. Within this data set, increases in CNCPS estimated metabolizable Lys had no multivariable association with milk yield, milk protein yield, or content. It is always possible that use of a different nutritional model could provide a different assessment of the Lys responses. Further work is necessary to evaluate milk and milk protein responses to diets with greater amounts of Lys and greater treatment differences as well as in data sets with transition and early lactation cows represented more fully.

\section{ACKNOWLEDGMENTS}

This study was partially supported by funds from Kemin Industries (Des Moines, IA). The authors thank the reviewers for important insights and time contributed to the paper.

\section{REFERENCES}

Abdelqader, M. M., and M. Oba. 2012. Lactation performance of dairy cows fed increasing concentrations of wheat dried distillers grains with solubles. J. Dairy Sci. 95:3894-3904.

Abu-Ghazaleh, A. A., D. J. Schingoethe, and A. R. Hippen. 2001. Blood amino acids and milk composition from cows fed soybean meal, fish meal, or both. J. Dairy Sci. 84:1174-1181.

Akayezu, J. M., W. P. Hansen, D. E. Otterby, B. A. Crooker, and G. D. Marx. 1997. Yield response of lactating Holstein dairy cows to dietary fish meal or meat and bone meal. J. Dairy Sci. 80:29502963.

Alstrup, L., M. R. Weisbjerg, L. Hymøller, M. K. Larsen, P. Lund, and M. O. Nielsen. 2014. Milk production response to varying protein supply is independent of forage digestibility in dairy cows. J. Dairy Sci. 97:4412-4422.

Appuhamy, J. A. D. R. N., J. R. Knapp, O. Becvar, J. Escobar, and M. D. Hanigan. 2011. Effects of jugular-infused lysine, methionine, and branched-chain amino acids on milk protein synthesis in highproducing dairy cows. J. Dairy Sci. 94:1952-1960.

Arriola Apelo, S. I., A. L. Bell, K. Estes, J. Ropelewski, M. J. de Veth, and M. D. Hanigan. 2014. Effects of reduced dietary protein and supplemental rumen-protected essential amino acids on the nitrogen efficiency of dairy cows. J. Dairy Sci. 97:5688-5699.

Bach, A., G. B. Huntington, S. Calsamiglia, and M. D. Stern. 2000 Nitrogen metabolism of early lactation cows fed diets with two different levels of protein and different amino acid profiles. J. Dairy Sci. 83:2585-2595.

Bahrami-Yekdangi, H., M. Khorvash, G. R. Ghorbani, M. Alikhani, R. Jahanian, and E. Kamalian. 2014. Effects of decreasing metabolizable protein and rumen-undegradable protein on milk production and composition and blood metabolites of Holstein dairy cows in early lactation. J. Dairy Sci. 97:3707-3714.

Baker, L. D., J. D. Ferguson, and W. Chalupa. 1995. Responses in urea and true protein of milk to different protein feeding schemes for dairy cows. J. Dairy Sci. 78:2424-2434.

Blauwiekel, R., W. H. Hoover, S. D. Slider, and T. K. Miller. 1990 Effects of fish meal protein supplementation on milk yield and composition and blood constituents of dairy cows. J. Dairy Sci. 73:3217-3221.

Borenstein, M., J. P. T. Higgins, L. V. Hedges, and H. R. Rothstein. 2017. Basics of meta-analysis: $I^{2}$ is not an absolute measure of heterogeneity. Res. Synth. Methods 8:5-18.

Borucki Castro, S. I., L. E. Phillip, H. Lapierre, P. W. Jardon, and R. Berthiaume. 2008. The relative merit of ruminal undegradable protein from soybean meal or soluble fiber from beet pulp to improve nitrogen utilization in dairy cows. J. Dairy Sci. 91:3947-3957.

Brake, D. W., E. C. Titgemeyer, M. J. Brouk, C. A. Macgregor, J. F. Smith, and B. J. Bradford. 2013. Availability to lactating dairy cows of methionine added to soy lecithins and mixed with a mechanically extracted soybean meal. J. Dairy Sci. 96:3064-3074.

Brito, A. F., and G. A. Broderick. 2007. Effects of different protein supplements on milk production and nutrient utilization in lactating dairy cows. J. Dairy Sci. 90:1816-1827.

Broderick, G. A., M. J. Stevenson, and R. A. Patton. 2009. Effect of dietary protein concentration and degradability on response to rumen-protected methionine in lactating dairy cows. J. Dairy Sci. 92:2719-2728.

Broderick, G. A., M. J. Stevenson, R. A. Patton, N. E. Lobos, and J. J. Olmos Colmenero. 2008. Effect of supplementing rumen-protected methionine on production and nitrogen excretion in lactating dairy cows. J. Dairy Sci. 91:1092-1102.

Cermakova, J., V. Kudrna, J. Illek, K. Blazkova, and J. Haman. 2012. Effects of a rumen-protected form of methionine and a methionine analogue on the lactation performance of dairy cows. Czech J. Anim. Sci. 57:410-419.

Chamberlain, D. G., and J.-M. Yeo. 2003. Effects of amino acids on milk production. Pages 367-387 in Amino Acids in Animal Nutrition. 2nd ed. J. P. F. D'Mello, ed. CABI Publishing, Wallingford, UK.

Cheng, J., L. J. Edwards, M. M. Maldonado-Molino, K. A. Kondro, and K. E. Muller. 2010. Real longitudinal data analysis for real people: Building a good enough mixed model. Stat. Med. 29:504520.

Chibisa, G. E., D. A. Christensen, and T. Mutsvangwa. 2012. Effects of replacing canola meal as the major protein source with wheat dried distillers grains with solubles on ruminal function, microbial protein synthesis, omasal flow, and milk production in cows. J. Dairy Sci. 95:824-841.

Christen, K. A., D. J. Schingoethe, K. F. Kalscheur, A. R. Hippen, K. K. Karges, and M. L. Gibson. 2010. Response of lactating dairy cows to high protein distillers grains or 3 other protein supplements. J. Dairy Sci. 93:2095-2104.

Cyriac, J., A. G. Rius, M. L. McGilliard, R. E. Pearson, B. J. Bequette, and M. D. Hanigan. 2008. Lactation performance of mid- 
lactation dairy cows fed ruminally degradable protein at concentrations lower than National Research Council recommendations. J. Dairy Sci. 91:4704-4713.

Dalbach, K. F., M. Larsen, B. M. L. Raun, and N. B. Kristensen. 2011. Effects of supplementation with 2-hydroxy-4-(methylthio)butanoic acid isopropyl ester on splanchnic amino acid metabolism and essential amino acid mobilization in postpartum transition Holstein cows. J. Dairy Sci. 94:3913-3927.

Davidson, S., B. A. Hopkins, D. E. Diaz, S. M. Bolt, C. Brownie, V. Fellner, and L. W. Whitlow. 2003. Effects of amounts and degradability of dietary protein on lactation, nitrogen utilization, and excretion in early lactation Holstein cows. J. Dairy Sci. 86:16811689.

DerSimonian, R., and N. Laird. 1986. Meta-analysis in clinical trials. Control. Clin. Trials 7:177-188.

Dinn, N. E., J. A. Shelford, and L. J. Fisher. 1998. Use of the Cornell Net Carbohydrate and Protein System and rumen-protected lysine and methionine to reduce nitrogen excretion from lactating dairy cows. J. Dairy Sci. 81:229-237.

Doepel, L., and H. Lapierre. 2010. Changes in production and mammary metabolism of dairy cows in response to essential and nonessential amino acid infusions. J. Dairy Sci. 93:3264-3274.

Doepel, L., and H. Lapierre. 2011. Deletion of arginine from an abomasal infusion of amino acids does not decrease milk protein yield in Holstein cows. J. Dairy Sci. 94:864-873.

Doepel, L., D. Pacheco, J. J. Kennelly, M. D. Hanigan, I. F. Lopez, and H. Lapierre. 2004. Milk protein synthesis as a function of amino acid supply. J. Dairy Sci. 87:1279-1297.

Dohoo, I., W. Martin, and H. Stryhn. 2009. Model building strategies. Pages 370-371 in Veterinary Epidemiologic Research. 2nd ed. University of Prince Edward Island, Charlottetown, PE, Canada.

Echambadi, R., and J. D. Hess. 2007. Mean-centering does not alleviate collinearity problems in moderated multiple regression models. Mark. Sci. 26:438-445.

Egger, M., and G. D. Smith. 2001. Principles of and procedures for systematic reviews. Pages 23-42 in Systematic Reviews of Health Care: Meta-Analysis in Context. M. Egger, G. Davey Smith, and D. G. Altman, ed. British Medical Journal Books, London, UK.

Ellison Henson, J., D. J. Schingoethe, and H. A. Maiga. 1997. Lactational evaluation of protein supplements of varying ruminal degradabilities. J. Dairy Sci. 80:385-392.

Erasmus, L. J., Z. Bester, and R. J. Coertze. 2013. Milk composition as technique to evaluate the relative bioavailability of a liquid rumen protected methionine source. S. Afr. J. Anim. Sci. 43:S86-S92.

Galindo, C. E., D. R. Ouellet, D. Pellerin, S. Lemosquet, I. OrtiguesMarty, and H. Lapierre. 2011. Effect of amino acid or casein supply on whole-body, splanchnic, and mammary glucose kinetics in lactating dairy cows. J. Dairy Sci. 94:5558-5568.

Giallongo, F., A. N. Hristov, J. Oh, T. Frederick, H. Weeks, J. Werner, H. Lapierre, R. A. Patton, A. Gehman, and C. Parys. 2015. Effects of slow-release urea and rumen-protected methionine and histidine on performance of dairy cows. J. Dairy Sci. 98:3292-3308.

Girard, C. L., H. Lapierre, J. J. Matte, and G. E. Lobley. 2005. Effects of dietary supplements of folic acid and rumen-protected methionine on lactational performance and folate metabolism of dairy cows. J. Dairy Sci. 88:660-670.

Guzik, A. C., L. L. Southern, T. D. Bidner, and B. J. Kerr. 2002. The tryptophan requirement of nursery pigs. J. Anim. Sci. 80:26462655.

Hadrova, S., L. Krizova, M. Richter, J. Trinacty, and M. Drackova. 2012. The effect of duodenal infusion of histidine on milk yield, milk composition, and plasma amino acids in dairy cows. J. Anim. Feed Sci. 21:555-565.

Hall, M. B., C. C. Larson, and C. J. Wilcox. 2010. Carbohydrate source and protein degradability alter lactation, ruminal, and blood measures. J. Dairy Sci. 93:311-322.

Haque, M. N., H. Rulquin, A. Andrade, P. Faverdin, J. L. Peyraud, and S. Lemosquet. 2012. Milk protein synthesis in response to the provision of an "ideal" amino acid profile at 2 levels of metabolizable protein supply in dairy cows. J. Dairy Sci. 95:5876-5887.
Haque, M. N., H. Rulquin, and S. Lemosquet. 2013. Milk protein responses in dairy cows to changes in postruminal supplies of arginine, isoleucine, and valine. J. Dairy Sci. 96:420-430.

Harbord, R. M., and J. P. T. Higgins. 2008. Meta-regression in Stata. Stata J. 8:493-519.

Harbord, R. M., and T. J. Steichen. 2004. METAREG: Stata module to perform meta-analysis regression. Statistical Software Components S4446201, Boston College, Boston, MA.

Hedges, L. V., E. Tipton, and M. Johnson. 2010. Robust variance estimation in meta-regression with dependent effect size estimates. Res. Synth. Methods 1:39-65.

Higgins, J. P. T., and S. G. Thompson. 2002. Quantifying heterogeneity in a meta-analysis. Stat. Med. 21:1539-1558.

Higgins, J. P. T., and S. G. Thompson. 2004. Controlling the risk of spurious findings from meta-regression. Stat. Med. 23:1663-1682.

Higgs, R. J., L. E. Chase, D. A. Ross, and M. E. Van Amburgh. 2015 Updating the Cornell Net Carbohydrate and Protein System feed library and analyzing model sensitivity to feed inputs. J. Dairy Sci. 98:6340-6360.

Higgs, R. J., L. E. Chase, and M. E. Van Amburgh. 2012. Development and evaluation of equations in the Cornell Net Carbohydrate and Protein System to predict nitrogen excretion in lactating dairy cows. J. Dairy Sci. 95:2004-2014.

Johnson-VanWieringen, L. M., J. H. Harrison, D. Davidson, M. L. Swift, M. A. G. von Keyserlingk, M. Vazquez-Anon, D. Wright, and W. Chalupa. 2007. Effects of rumen-undegradable protein sources and supplemental 2-hydroxy-4-(methylthio)-butanoic acid and lysine $\cdot \mathrm{HCl}$ on lactation performance in dairy cows. J. Dairy Sci. 90:5176-5188.

Knapp, G., and J. Hartung. 2003. Improved tests for a random-effects meta-regression with a single covariate. Stat. Med. 22:2693-2710.

Korhonen, M., A. Vanhatalo, and P. Huhtanen. 2002. Effect of protein source on amino acid supply, milk production, and metabolism of plasma nutrients in dairy cows fed grass silage. J. Dairy Sci. 85:3336-3351.

Larsen, M., H. Lapierre, and N. B. Kristensen. 2014. Abomasal protein infusion in postpartum transition dairy cows: Effect on performance and mammary metabolism. J. Dairy Sci. 97:5608-5622.

Lean, I. J., A. R. Rabiee, T. F. Duffield, and I. R. Dohoo. 2009. Invited review: Use of meta-analysis in animal health and reproduction: Methods and applications. J. Dairy Sci. 92:3545-3565.

Lee, C., A. N. Hristov, T. W. Cassidy, K. S. Heyler, H. Lapierre, G. A. Varga, M. J. de Veth, R. A. Patton, and C. Parys. 2012b. Rumenprotected lysine, methionine, and histidine increase milk protein yield in dairy cows fed a metabolizable protein-deficient diet. J. Dairy Sci. 95:6042-6056.

Lee, C., A. N. Hristov, K. S. Heyler, T. W. Cassidy, H. Lapierre, G. A. Varga, and C. Parys. 2012a. Effects of metabolizable protein supply and amino acid supplementation on nitrogen utilization, milk production, and ammonia emissions from manure in dairy cows. J. Dairy Sci. 95:5253-5268.

Lellis, W. A., and V. C. Speer. 1987. Phenylalanine requirement of the lactating sow. J. Anim. Sci. 65:1006-1012.

Leonardi, C., M. Stevenson, and L. E. Armentano. 2003. Effect of two levels of crude protein and methionine supplementation on performance of dairy cows. J. Dairy Sci. 86:4033-4042.

Liu, C., D. J. Schingoethe, and G. A. Stegeman. 2000. Corn distillers grains versus a blend of protein supplements with or without ruminally protected amino acids for lactating cows. J. Dairy Sci. 83:2075-2084.

Mackle, T. R., D. A. Dwyer, and D. E. Bauman. 1999. Effects of branched-chain amino acids and sodium caseinate on milk protein concentration and yield from dairy cows. J. Dairy Sci. 82:161-171.

Mepham, T. B. 1982. Amino acid utilization by lactating mammary gland. J. Dairy Sci. 65:287-298.

Mjoun, K., K. F. Kalscheur, A. R. Hippen, and D. J. Schingoethe. 2010b. Performance and amino acid utilization of early lactation dairy cows fed regular or reduced-fat dried distillers grains with soluble. J. Dairy Sci. 93:3176-3191. 
Mjoun, K., K. F. Kalscheur, A. R. Hippen, D. J. Schingoethe, and D. E. Little. 2010a. Lactation performance and amino acid utilization of cows fed increasing amounts of reduced-fat dried distillers grains with soluble. J. Dairy Sci. 93:288-303.

Moussavi, A. R., R. O. Gilbert, T. R. Overton, D. E. Bauman, and W. R. Butler. 2007. Effects of feeding fish meal and n-3 fatty acids on milk yield and metabolic responses in early lactating dairy cows. J. Dairy Sci. 90:136-144.

Mullins, C. R., D. Weber, E. Block, J. F. Smith, M. J. Brouk, and B. J. Bradford. 2013. Supplementing lysine and methionine in a lactation diet containing a high concentration of wet corn gluten feed did not alter milk protein yield. J. Dairy Sci. 96:5300-5305.

NRC. 2001. Nutrient Requirements of Dairy Cattle. 7th rev. ed. Natl. Acad. Sci., Washington, DC.

Noftsger, S., and N. R. St-Pierre. 2003. Supplementation of methionine and selection of highly digestible rumen undegradable protein to improve nitrogen efficiency for milk production. J. Dairy Sci. 86:958-969.

Osorio, J. S., C. B. Jacometo, Z. Zhou, D. Luchini, F. C. Cardoso, and J. J. Loor. 2016. Hepatic global DNA and peroxisome proliferatoractivated receptor alpha promoter methylation are altered in peripartal dairy cows fed rumen-protected methionine. J. Dairy Sci. 99:234-244.

Overton, T. R., L. S. Emmert, and J. H. Clark. 1998. Effects of source of carbohydrate and protein and rumen-protected methionine on performance of cows. J. Dairy Sci. 81:221-228.

Patton, R. A. 2010. Effect of rumen-protected methionine on feed intake, milk production, true milk protein concentration, and true milk protein yield, and the factors that influence these effects: A meta-analysis. J. Dairy Sci. 93:2105-2118.

Paz, H. A., M. J. de Veth, R. S. Ordway, and P. J. Kononoff. 2013. Evaluation of rumen-protected lysine supplementation to lactating dairy cows consuming increasing amounts of distillers dried grains with soluble. J. Dairy Sci. 96:7210-7222.

Phipps, R. H., C. K. Reynolds, D. I. Givens, A. K. Jones, P.-A. Geraert, E. Devillard, and R. Bennett. 2008. Short communication: Effects of 2-hydroxy-4-(methylthio) butanoic acid isopropyl ester on milk production and composition of lactating Holstein dairy cows. J. Dairy Sci. 91:4002-4005.

Polan, C. E., G. Cozzi, P. Berzaghi, and I. Andrighetto. 1997. A blend of animal and cereal protein or fish meal as partial replacement for soybean meal in the diets of lactating Holstein cows. J. Dairy Sci. 80:160-166.

Pruekvimolphan, S., and R. R. Grummer. 2001. Lactation responses to sulfur-containing amino acids from feather meal or rumen-protected methionine. J. Dairy Sci. 84:2515-2522.

Rabe-Hesketh, S., and A. Skrondal. 2005. Multilevel and longitudinal modeling using Stata. Stata Press, College Station, TX.

Rabiee, A. R., K. Breinhild, W. Scott, H. M. Golder, E. Block, and I. J. Lean. 2012. Effect of fat additions to diets of dairy cattle on milk production and components: A meta-analysis and metaregression. J. Dairy Sci. 95:3225-3247.

Raggio, G., D. Pacheco, R. Berthiaume, G. E. Lobley, D. Pellerin, G. Allard, P. Dubreuil, and H. Lapierre. 2004. Effect of level of metabolizable protein on splanchnic flux of amino acids in lactating dairy cows. J. Dairy Sci. 87:3461-3472.

Reynal, S. M., and G. A. Broderick. 2003. Effects of feeding dairy cows protein supplements of varying ruminal degradability. J. Dairy Sci. 86:835-843.

Rius, A. G., M. L. McGilliard, C. A. Umberger, and M. D. Hanigan. 2010. Interactions of energy and predicted metabolizable protein in determining nitrogen efficiency in the lactating dairy cow. J. Dairy Sci. 93:2034-2043.

Robinson, P. H., W. Chalupa, C. J. Sniffen, W. E. Julien, H. Sato, T. Fujieda, K. Watanabe, and H. Suzuki. 1999. Influence of postruminal supplementation of methionine and lysine, isoleucine, or all three amino acids on intake and chewing behavior, ruminal fermentation, and milk and milk component production. J. Anim. Sci. 77:2781-2792.
Robinson, P. H., N. Swanepoel, and E. Evans. 2010. Effects of feeding a ruminally protected lysine product, with or without isoleucine, valine and histidine, to lactating dairy cows on their productive performance and plasma amino acid profiles. Anim. Feed Sci. Technol. 161:75-84.

Rulquin, H., and P. M. Pisulewski. 2006. Effects of graded levels of duodenal infusions of leucine on mammary uptake and output in lactating dairy cows. J. Dairy Res. 73:328-339.

Rulquin, H., P. M. Pisulewski, R. Verite, and J. Guinard. 1993. Milk production and composition as a function of postruminal lysine and methionine supply: A nutrient-response approach. Livest. Prod. Sci. 37:69-90.

Schwab, C. G., C. K. Bozak, N. L. Whitehouse, and M. M. A. Mesbah. 1992. Amino acid limitation and flow to duodenum at four stages of lactation. 1. Sequence of lysine and methionine limitation. J. Dairy Sci. 75:3486-3502.

Socha, M. T., D. E. Putnam, B. D. Garthwaite, N. L. Whitehouse, N. A. Kierstead, C. G. Schwab, G. A. Ducharme, and J. C. Robert. 2005. Improving intestinal amino acid supply of pre- and postpartum dairy cows with rumen-protected methionine and lysine. J. Dairy Sci. 88:1113-1126.

St-Pierre, N. R. 2001. Integrating quantitative findings from multiple studies using mixed model methodology. J. Dairy Sci. 84:741-755.

Sullivan, M. L., K. N. Grigsby, and B. J. Bradford. 2012. Effects of wet corn gluten feed on ruminal $\mathrm{pH}$ and productivity of lactating dairy cattle fed diets with sufficient physically effective fiber. J. Dairy Sci. 95:5213-5220.

Swanepoel, N., P. H. Robinson, and L. J. Erasmus. 2014. Determining the optimal ratio of canola meal and high protein dried distillers grain protein in diets of high producing Holstein dairy cows. Anim. Feed Sci. Technol. 189:41-53.

Tanner-Smith, E. E., and E. Tipton. 2014. Robust variance estimation with dependent effect sizes: Practical considerations including a software tutorial in Stata and SPSS. Res. Synth. Methods 5:13-30.

Thompson, S. G., and S. J. Sharp. 1999. Explaining heterogeneity in meta-analysis: A comparison of methods. Stat. Med. 18:2693-2708.

Van Amburgh, M. E., E. A. Collao-Saenz, R. J. Higgs, D. A. Ross, E. B. Recktenwald, E. Raffrenato, L. E. Chase, T. R. Overton, J. K. Mills, and A. Foskolos. 2015. The Cornell Net Carbohydrate and Protein System: Updates to the model and evaluation of version 6.5. J. Dairy Sci. 98:6361-6380.

Van Amburgh, M. E., A. Foskolos, E. A. Collao-Saenz, R. J. Higgs, and D. A. Ross. 2013. Updating the CNCPS feed library with new feed amino acid profiles and efficiencies of use: Evaluation of model predictions-version 6.5. Pages 59-76 in Proc. Cornell Nutrition Conference for Feed Manufacturers, East Syracuse, NY.

Van den Noortgate, W., J. A. Lopez-Lopez, F. Marin-Martinez, and J. Sanchez-Meca. 2013. Three level meta-analysis of dependent effect sizes. Behav. Res. Methods 45:576-594.

Vanhatalo, A., T. Varvikko, and P. Huhtanen. 2003. Effects of casein and glucose on responses of cows fed diets based on restrictively fermented grass silage. J. Dairy Sci. 86:3260-3270.

Vargas-Rodriguez, C. F., K. Yuan, E. C. Titgemeyer, L. K. Mamedova, K. E. Griswold, and B. J. Bradford. 2014. Effects of supplemental chromium propionate and rumen-protected amino acids on productivity, diet digestibility, and energy balance of peak-lactation dairy cattle. J. Dairy Sci. 97:3815-3821.

Vite, A. A., A. G. Alvarez, A. P. Marquez, M. F. Montano, N. G. Torrentera, and R. Zinn. 2013. Influence of abomasal infusion of phenylalanine on characteristics of digestion of a steam-flaked wheat-based finishing diet fed to Holstein steers. J. Anim. Sci. 91(Suppl.):E10.

Vyas, D., and R. A. Erdman. 2009. Meta-analysis of milk protein yield responses to lysine and methionine supplementation. J. Dairy Sci. 92:5011-5018

Wang, C., J. X. Liu, Z. P. Yuan, Y. M. Wu, S. W. Zhai, and H. W. Ye. 2007. Effect of level of metabolizable protein on milk production and nitrogen utilization in lactating dairy cows. J. Dairy Sci. 90:2960-2965. 
Weekes, T. L., P. H. Luimes, and J. P. Cant. 2006. Responses to amino acid imbalances and deficiencies in lactating dairy cows. J. Dairy Sci. 89:2177-2187.

Whelan, S. J., F. J. Mulligan, B. Flynn, C. McCarney, and K. M. Pierce. 2011. Effect of forage source and a supplementary methionine hydroxyl analog on nitrogen balance in lactating dairy cows offered a low crude protein diet. J. Dairy Sci. 94:5080-5089.

White, I. R., and J. Thomas. 2005. Standardized mean differences in individually-randomized and cluster-randomized trials, with applications to meta-analysis. Clin. Trials 2:141-151.

White, R. R., T. McGill, R. Garnett, R. J. Patterson, and M. D. Hanigan. 2017. Evaluation of the PREP10 energy-, protein-, and amino acid-allowable milk equations in comparison with the National Research Council model. J. Dairy Sci. 100:2801-2806.

\section{APPENDIX}

Further statistical analysis using only experiments with a significant Lys intervention (>20 g difference in lysine supply between treatments; 36 experiments) yielded results consistent with those of the entire data set (Appendix Figures A3, A4, and A5). Within the statistical models developed, milk protein percentage was associated with $(P<0.01)$ an increase of 0.031 ES with each additional gram of Met. Increases in Ile and NEAA were associated with an increased $(P<$ $0.01)$ milk protein yield of 0.007 and 0.002 ES per g, respectively. Nonessential AA was associated with an increased milk yield (0.002 ES) per gram. Lysine had no significant association with milk protein yield, milk protein percentage, or milk yield.

To investigate potential differences from the type of lysine intervention treatment, infusion versus fed, we conducted an effect size analysis (Appendix Table A4). Lysine intervention studies using infusions consistently produced greater effect size differences compared with treatments feeding Lys. Although the ES, overall, and for infused treatments only, indicate that Lys treatments increased production, the heterogeneity of these observations was high, indicating that treatment responses were very variable. Analysis of the data set did not indicate any differences in response to Lys based on the potential for dietary Lys source to be less available than predicted by the nutrition model (Appendix Table A5). The distribution of experiments with a potential Lys availability concerns versus no evident concern was similar for positive and negative responses to treatment (45 vs. $55 \%$ ). The mean increase in Lys for the positive responses was $11 \mathrm{~g} / \mathrm{d}$, whereas the mean decrease in Lys for the negative responses was $3.8 \mathrm{~g} / \mathrm{d}$. 


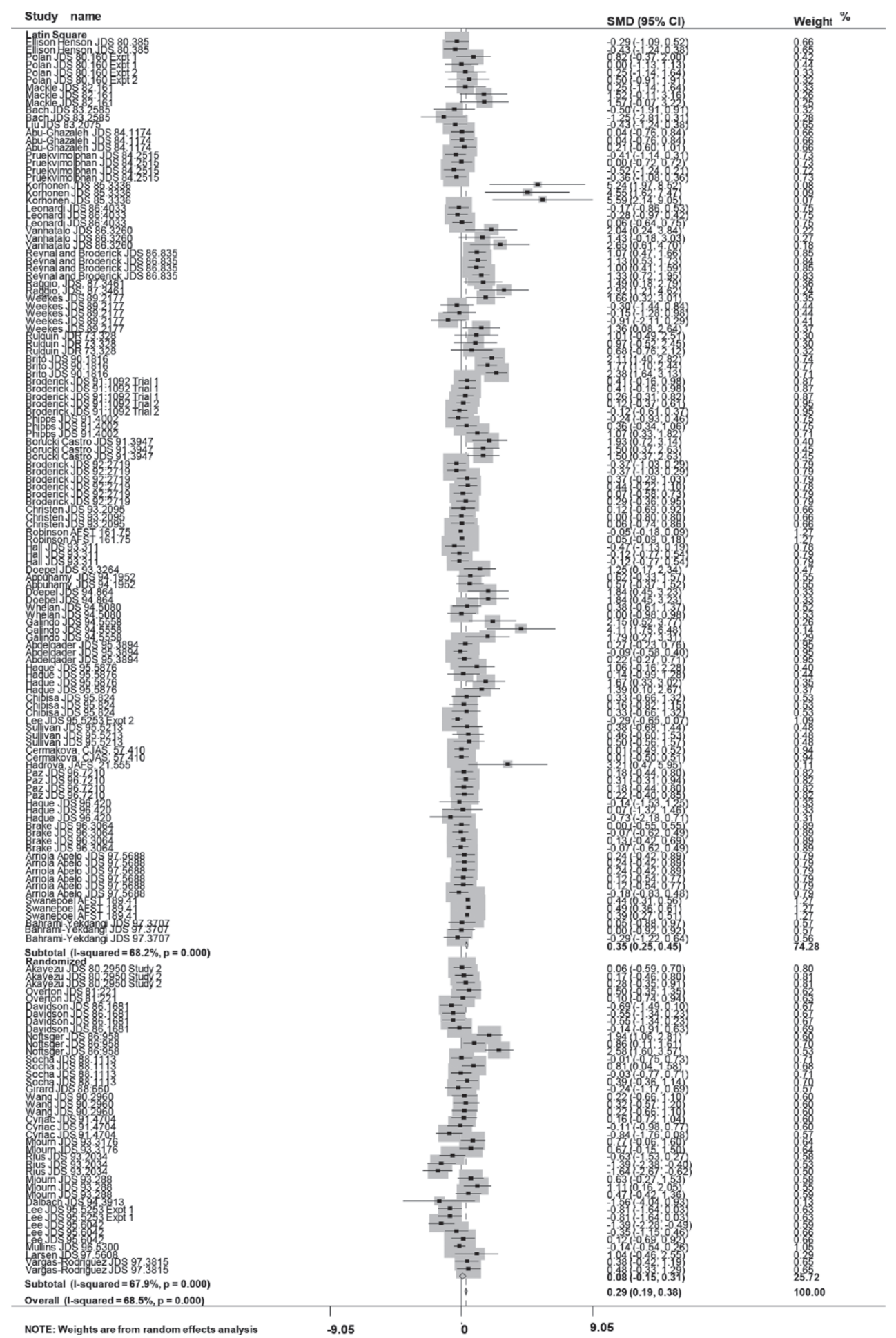

Figure A1. Forest plot of treatments examining the association between estimated MP AA and milk true protein yield (kg). Box sizes are proportional to the inverse variance of the estimates. Summary estimates of treatment effects (diamond shapes) using Latin square, completely randomized, and all studies (overall) are reported. Points to the left of the vertical line represent a reduction in the outcome, whereas points to the right of the line indicate an increase in the outcome variable. Each square represents the mean effect size for that treatment. The upper and lower limit of the line connected to the square represents the upper and lower $95 \%$ CI for the effect size. The weighting of a treatment is estimated by the inverse of the variance of the effect size. The size of the square box reflects the relative weighting of the treatment to the overall effect size estimate with larger squares representing greater weight. Boxes draw attention to the treatments with the greatest weight. The gray vertical line represents the mean difference of zero or no effect. AFST = Anim. Feed Sci. Technol.; JDR = J. Dairy Res.; CJAS = Czech J. Anim. Sci.; JAFS = J. Anim. Feed Sci.; JDS = J. Dairy Sci.; Expt. = experiment; SMD = standardized mean difference. 


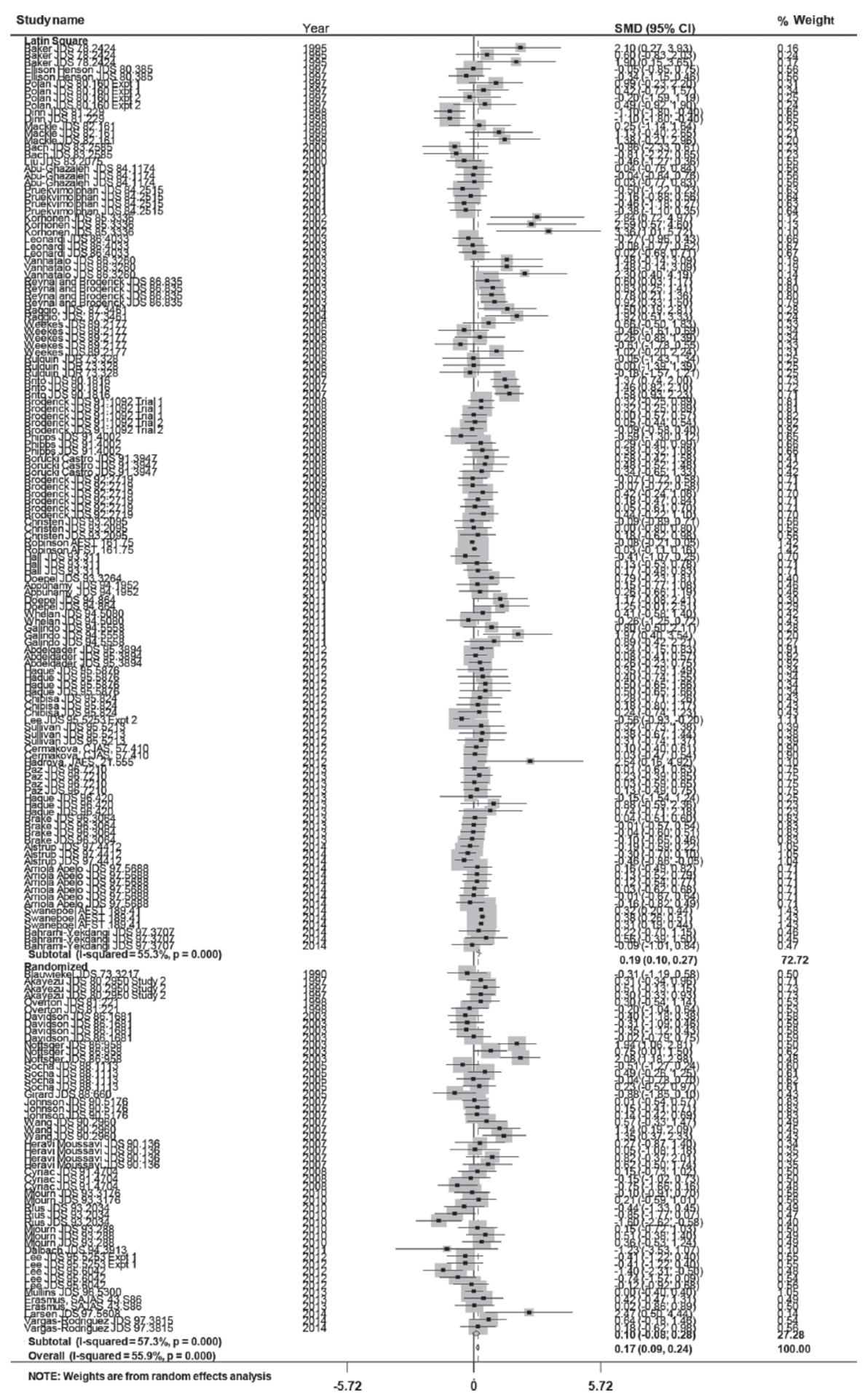

Figure A2. Forest plot of treatments examining the association between estimated MP AA and milk yield (kg). Box sizes are proportional to the inverse variance of the estimates. Summary estimates of treatment effects (diamond shapes) using Latin square, completely randomized, and all studies (overall) are reported. Points to the left of the vertical line represent a reduction in the outcome, whereas points to the right of the line indicate an increase in the outcome variable. Each square represents the mean effect size for that treatment. The upper and lower limit of the line connected to the square represents the upper and lower $95 \% \mathrm{CI}$ for the effect size. The weighting of a treatment is estimated by the inverse of the variance of the effect size. Box sizes are proportional to the inverse variance of the estimates. The size of the square box reflects the relative weighting of the study to the overall effect size estimate with larger squares representing greater weight. Boxes draw attention to the treatments with the greatest weight. The gray vertical line represents the mean difference of zero or no effect. AFST $=$ Anim. Feed Sci. Technol.; CJAS = Czech J. Anim. Sci.; JAES = J. Anim. Feed Sci.; JDS = J. Dairy Sci.; JDR = J. Dairy Res.; SAJAS = South African J. Anim. SCi.; Expt. = experiment; SMD $=$ standardized mean difference. 


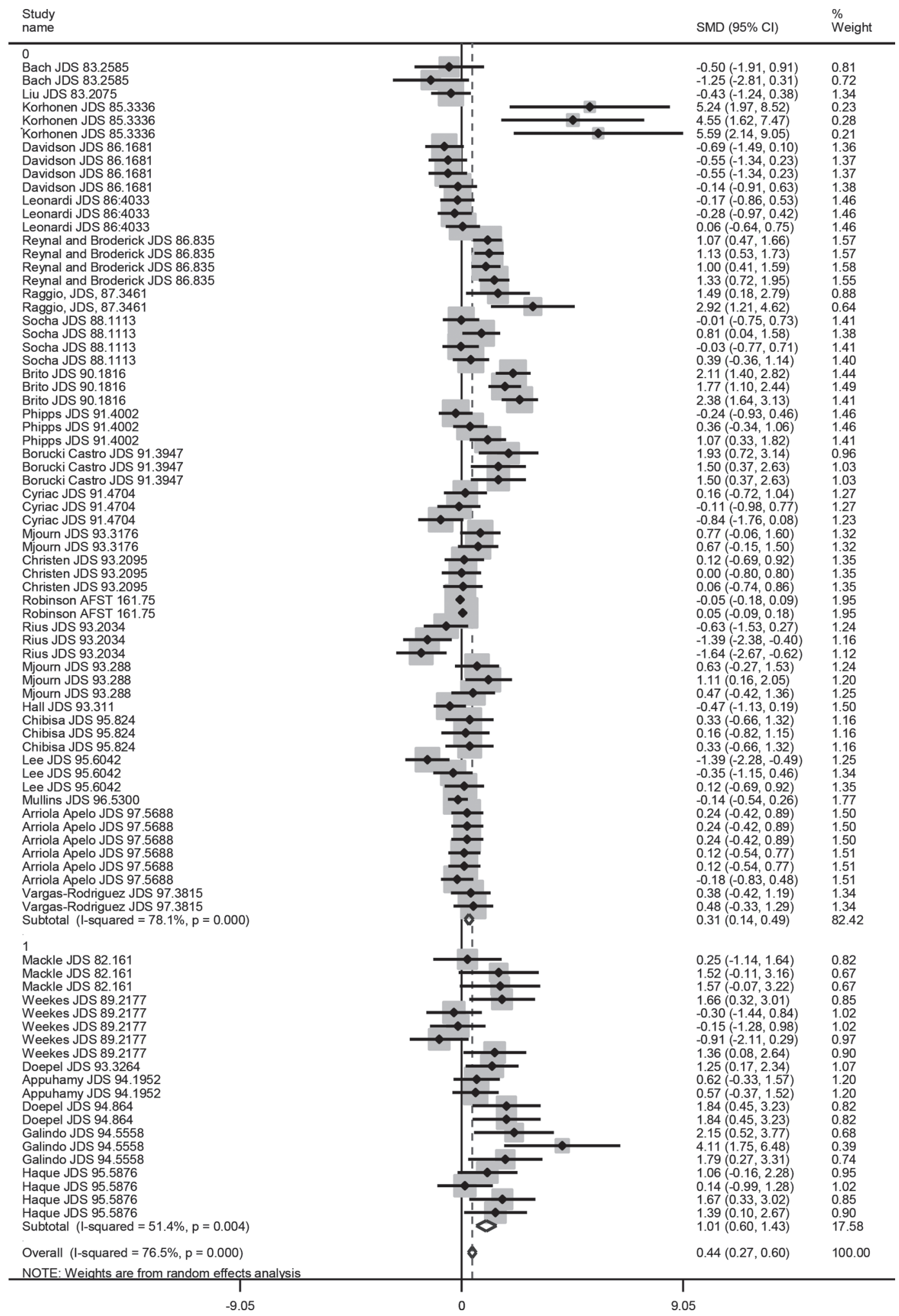

Figure A3. Forest plot of treatments examining the association between estimated MP AA and milk true protein (TP) yield (kg) in treatments that were considered Lys interventions. Box sizes are proportional to the inverse variance of the estimates. Summary estimates of treatment effects (diamond shapes) using Latin square, completely randomized, and all treatments (overall) are reported. AFST = Anim. Feed Sci. Technol.; JDS = J. Dairy Sci.; SMD = standardized mean difference. 


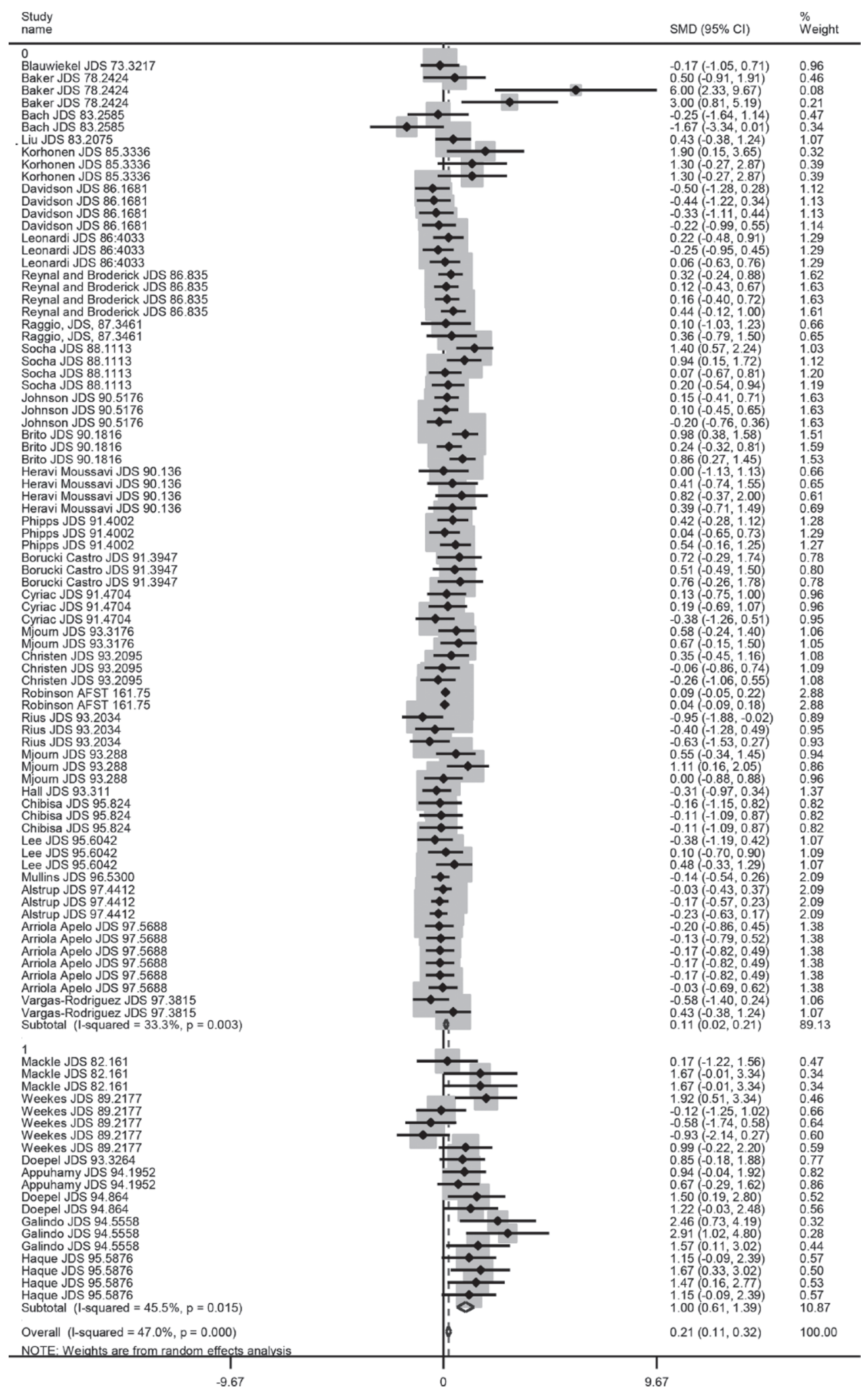

Figure A4. Forest plot of studies examining the association between estimated MP AA and milk true protein percentage in treatments that were considered Lys interventions. Box sizes are proportional to the inverse variance of the estimates. Summary estimates of treatment effects (diamond shapes) using Latin square, completely randomized, and all studies (overall) are reported. AFST $=$ Anim. Feed Sci. Technol.; JDS $=$ J. Dairy Sci.; SMD = standardized mean difference. 


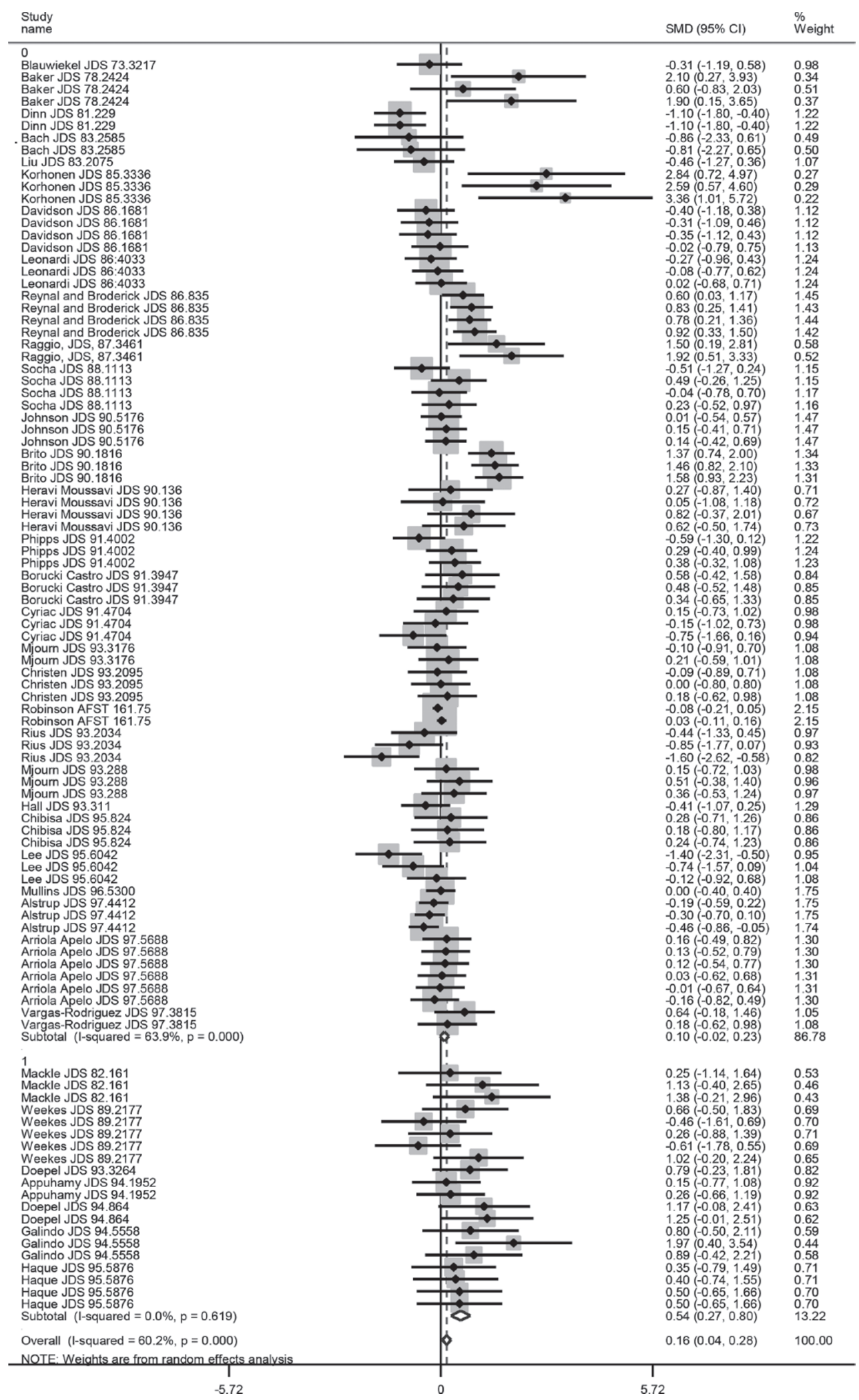

Figure A5. Forest plot of treatments examining the association between estimated MP AA and milk yield (kg) in treatments that were considered Lys interventions. Box sizes are proportional to the inverse variance of the estimates. Summary estimates of treatment effects (diamond shapes) using Latin square, completely randomized, and all studies (overall) are reported. AFST = Anim. Feed Sci. Technol.; JDS $=$ J. Dairy Sci.; SMD = standardized mean difference. 
Table A1. Studies rejected for inclusion in the meta-analysis with reasons for rejection

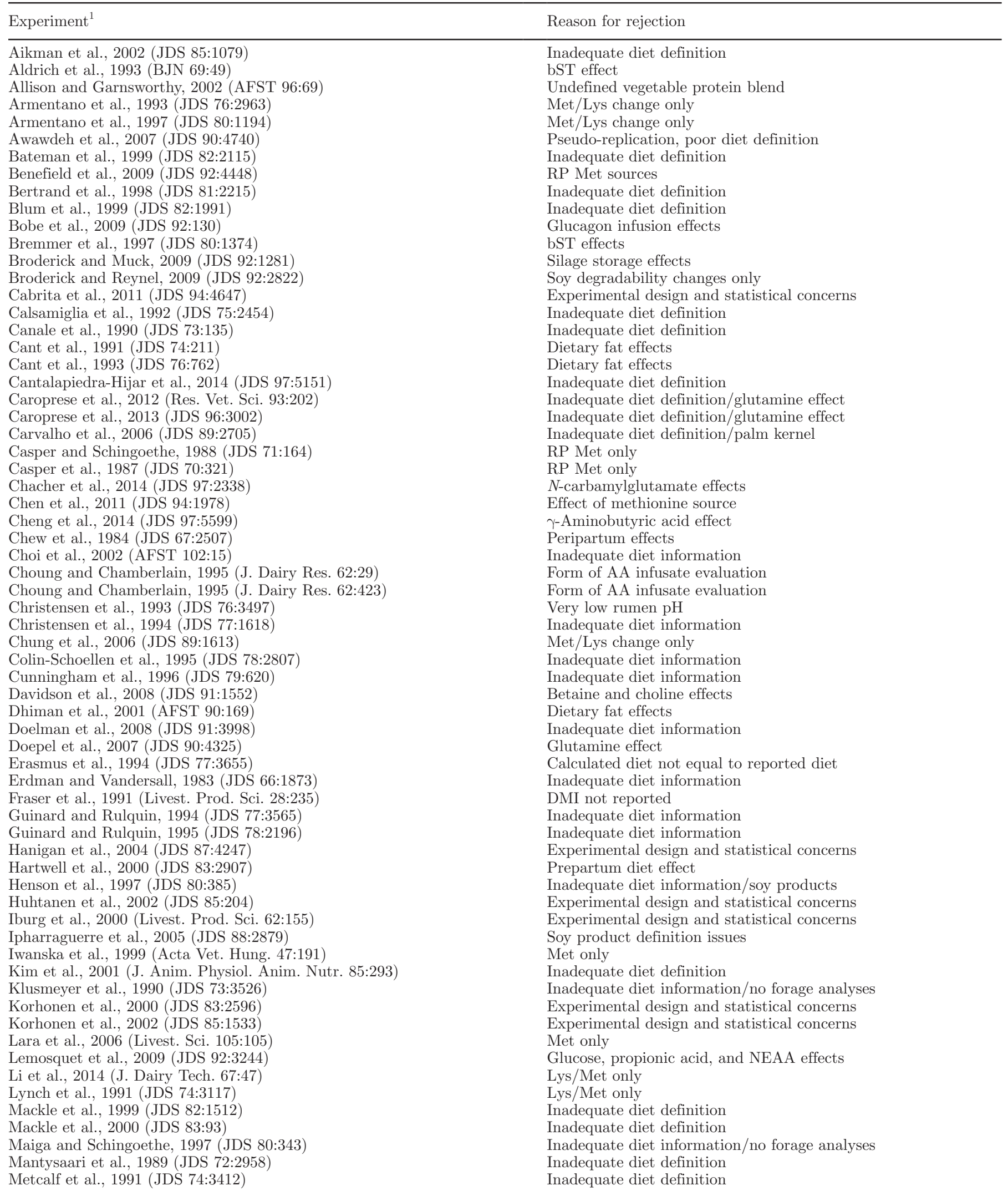


Table A1 (Continued). Studies rejected for inclusion in the meta-analysis with reasons for rejection

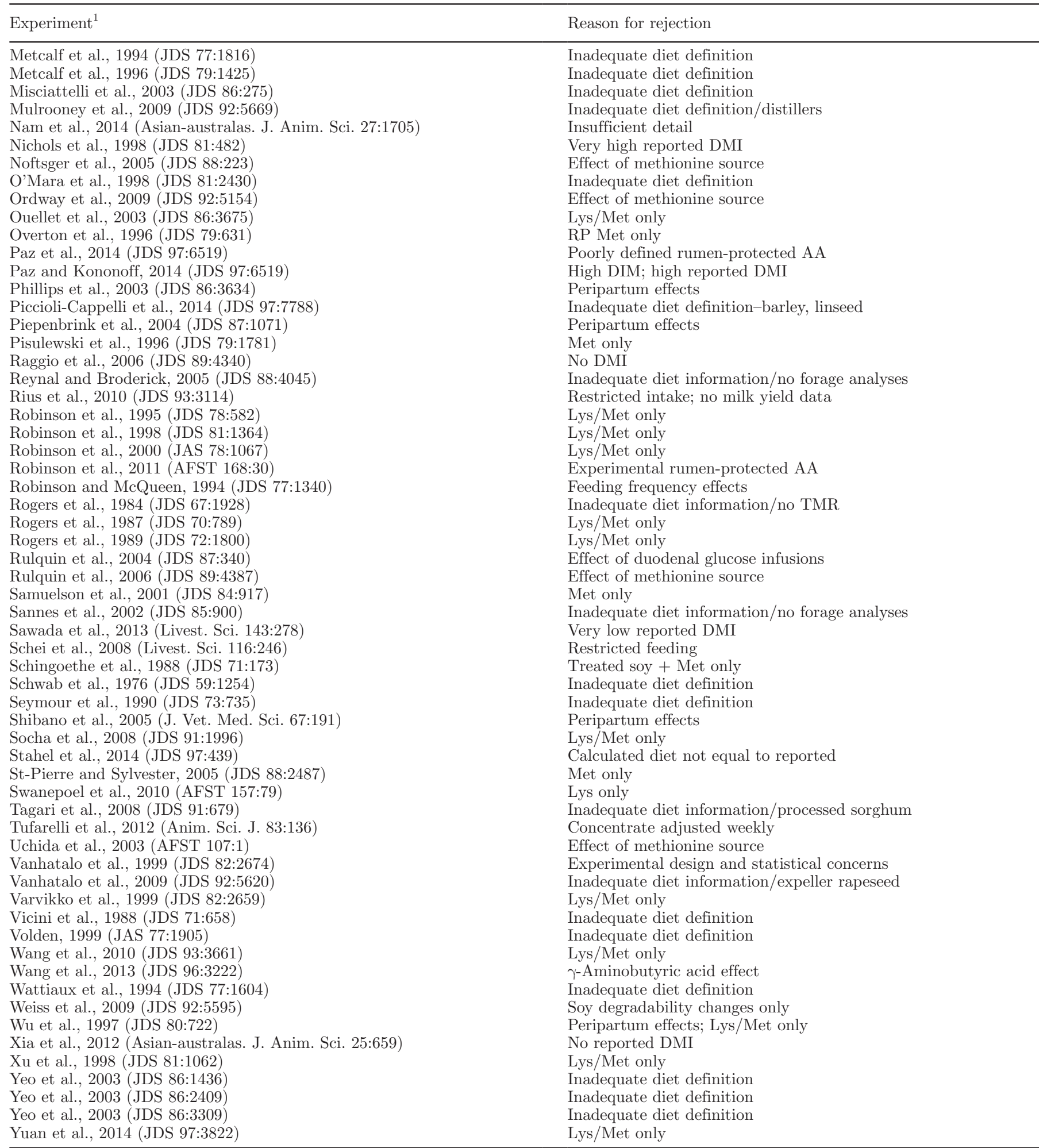

\footnotetext{
${ }^{1}$ AFST $=$ Anim. Feed Sci. Technol.; BJN = Br. J. Nutr.; JDS = J. Dairy Sci.; JAS = J. Anim. Sci.; RP = ruminally protected.
} 
Table A2. Variance inflation indexes (VIF) and condition indices calculated to assess collinearity for the mixed model evaluations

\begin{tabular}{lcc}
\hline & Milk TP $^{1}(\mathrm{~kg})$ & Milk yield $(\mathrm{kg})$ \\
Condition index & 4.21 & 3.85 \\
variable & VIF & VIF \\
\hline DIM & 1.52 & 1.16 \\
DIM $^{2}$ & 1.06 & 1.07 \\
Recombinant BST & 1.35 & 1.35 \\
Starch (kg) & 1.85 & 1.81 \\
Soluble fiber $(\mathrm{kg})$ & 1.63 & 1.59 \\
Ether extract $(\mathrm{kg})$ & - & 1.33 \\
Met $(\mathrm{g})$ & 2.38 & 3.41 \\
Leu $(\mathrm{g})$ & 3.72 & 3.20 \\
NEAA $(\mathrm{g})$ & 3.55 & 3.53 \\
\hline
\end{tabular}

${ }^{1} \mathrm{TP}=$ true protein.
Table A3. Variance inflation indexes and condition numbers calculated to assess collinearity for the classical model evaluations

\begin{tabular}{lcc}
\hline $\begin{array}{l}\text { Condition } \\
\text { number }\end{array}$ & Milk $\mathrm{TP}^{1}(\mathrm{~kg})$ & Milk yield $(\mathrm{kg})$ \\
variable & 1.73 & 1.96 \\
\hline Met $(\mathrm{g})$ & 1.33 & - \\
Leu $(\mathrm{g})$ & 1.33 & - \\
Trp $(\mathrm{g})$ & - & 1.53 \\
Thr $(\mathrm{g})$ & - & 1.53 \\
\hline
\end{tabular}

${ }^{1} \mathrm{TP}=$ true protein.

Table A4. Effect size analysis to predict milk TP yield, milk yield, and milk true protein (TP) percentage for all Lys intervention treatments (all), Lys intervention treatments with fed Lys (fed), and Lys intervention studies with infused Lys (infused)

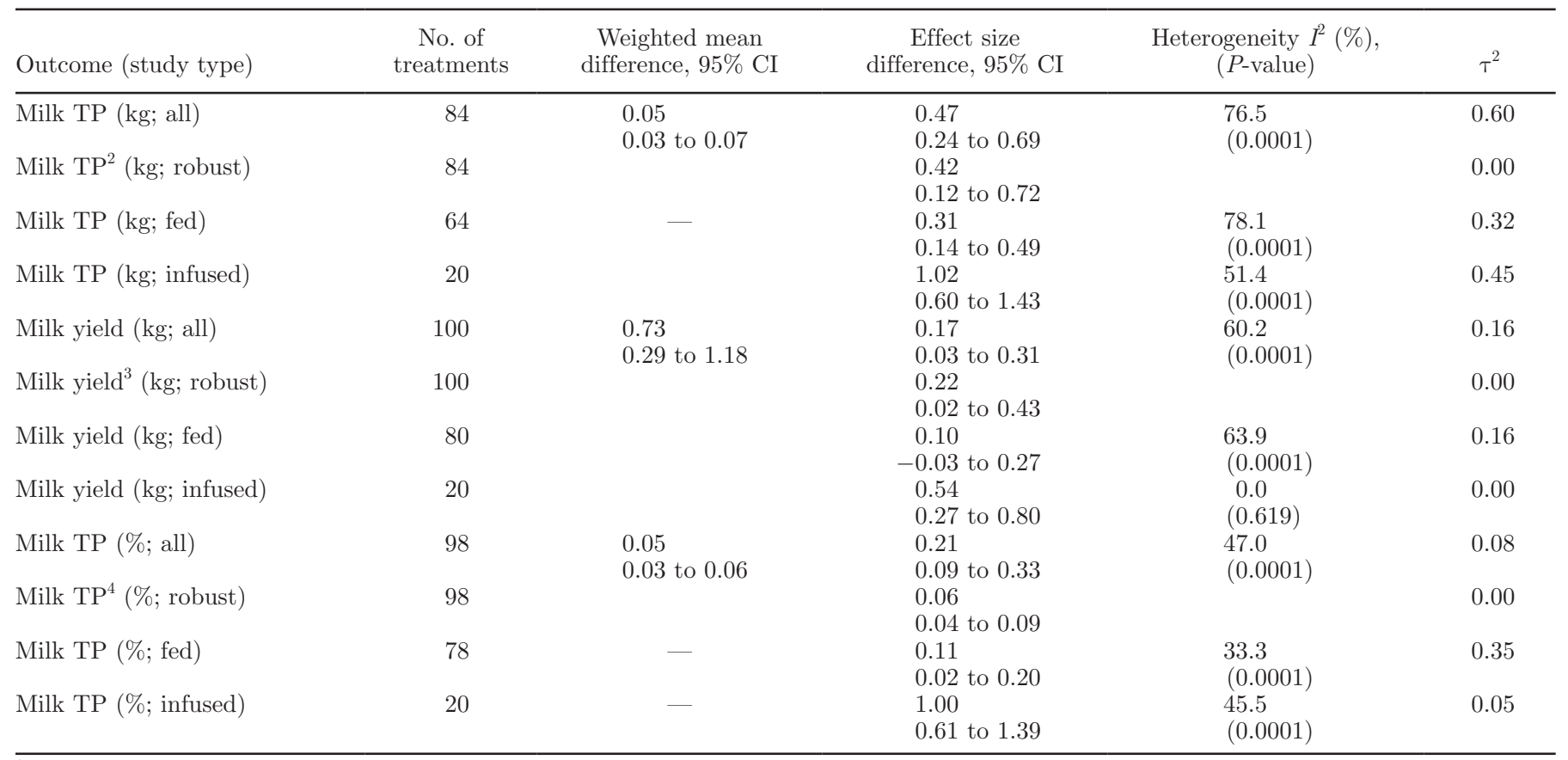

${ }^{1}$ Lysine interventions were defined as those with more than $20 \mathrm{~g} / \mathrm{d}$ difference in Cornell Net Carbohydrate and Protein System estimated metabolizable Lys between treated and controls. Number of treatments, weighted mean differences between intervention and control groups, effect size estimates, heterogeneity, and $\tau^{2}$ estimates for the studies. The overall estimates for milk TP yield, milk yield, and milk TP percentage were calculated with the Knapp-Hartung adjustments and using robust regression methods to account for nesting of treatments within experiment.

${ }^{2}$ Effect of experiment type (infusion or fed) 0.68 (95\% CI -0.09 to 1.46 ); $P=0.08$.

${ }^{3}$ Effect of experiment type (infusion or fed) 0.45 (95\% CI -0.05 to 0.94 ); $P=0.07$.

${ }^{4}$ Effect of experiment type (infusion or fed) 0.06 (95\% CI -0.02 to 0.13 ); $P=0.12$.

Table A5. Analysis of response to treatment by potential Lys availability concerns

\begin{tabular}{lccc}
\hline Item & $\begin{array}{c}\text { Availability concerns } \\
(\%)\end{array}$ & $\begin{array}{c}\text { N concerns } \\
(\%)\end{array}$ & $\begin{array}{c}\text { Lysine change } \\
(\mathrm{g} / \mathrm{d})\end{array}$ \\
\hline Milk (kg) & & & \\
$\quad$ Positive response & 44.3 & 55.7 & +11.55 \\
$\quad$ Negative response & 45.5 & 54.5 & -4.9 \\
True protein (kg) & & 56 & +10.28 \\
Positive response & 44 & 52.5 & -2.74 \\
Negative response & 47.5 & & \\
\hline
\end{tabular}

